\title{
REVIEW
}

\section{New frontiers in promoting tumour cell death: targeting apoptosis, necroptosis and autophagy}

\author{
JS Long and KM Ryan \\ Tumour Cell Death Laboratory, Beatson Institute for Cancer Research, Glasgow, UK
}

Cancer is a multifaceted disease comprising a combination of genetic, metabolic and signalling aberrations, which severely disrupt the normal homeostasis of cell growth and death. Many oncogenic events while promoting tumour development also increase the sensitivity of cells to cell death stimuli including chemotherapeutic drugs. As a result, tumour cells often acquire the ability to evade death by inactivating cell death pathways that normally function to eliminate damaged and harmful cells. The impairment of cell death function is also often the reason for the development of chemotherapeutic resistance encountered during treatment. It is therefore necessary to achieve a comprehensive understanding of existing cell death pathways and the relevant regulatory components involved, with the intention of identifying new strategies to kill cancer cells. This review provides an insightful overview of the common forms of cell death signalling pathways, the interactions between these pathways and the ways in which these pathways are deregulated in cancer. We also discuss the emerging therapies targeted at activating or restoring cell death pathways to induce tumour cell death, which are currently being tested in clinical trials.

Oncogene (2012) 31, 5045-5060; doi:10.1038/onc.2012.7; published online 6 February 2012

Keywords: cancer; apoptosis; necroptosis; autophagy; therapy

\section{Introduction}

Cell death is a process that is integral not only to normal physiological development and tissue homeostasis, but also as a defence mechanism against various forms of human disease (Solary et al., 1996; Greenhalgh, 1998; Miura, 2011). Hence, it is not surprising that defects in signalling pathways that mediate cell death can result in hyper-proliferative diseases such as cancer (Solary et al., 1996; Elmore, 2007).

Programmed cell death is a principle mechanism of tumour suppression and is triggered in non-malignant

Correspondence: Professor KM Ryan, Tumour Cell Death Laboratory, Beatson Institute for Cancer Research, Garscube Estate, Switchback Road, Glasgow G61 1BD, UK.

E-mail: k.ryan@beatson.gla.ac.uk

Received 17 October 2011; revised 24 December 2011; accepted 24 December 2011; published online 6 February 2012 cells as a protective mechanism to remove damaged and unhealthy cells that may otherwise harm the body. In addition, many of the oncogenes that become activated during tumour development push tumour cells closer to the edge of death, revealing a therapeutic window between normal and tumour cells that is the basis for many standard forms of chemotherapy (Green and Evan, 2002; Lowe et al., 2004). As a result, as tumours become more established and particularly following exposure to cell death-inducing therapies, a subset of defective cells carrying genetic aberrations can develop ways to inactivate or uncouple cell death pathways and evade irradication (Hanahan and Weinberg, 2000). Consequently, a population of death-resistant cells prevails and multiplies, accumulating additional genetic and epigenetic abnormalities, which ultimately culminates in malignant transformation. Although cancer cells can succumb to the harsh treatment of cytotoxic agents, many eventually acquire resistance to chemotherapy and continue to progress aggressively as the cells evolve means to circumvent death (McKenzie and Kyprianou, 2006).

As problems of poor prognosis and chemotherapy resistance are prevalent among cancer patients, the need for new strategies to eliminate cancer cells is paramount. For this purpose, it is imperative to revisit, update and understand the major pathways and components that control cell death, the defects within these pathways that are associated with cancer and the existing interplay between the pathways, in hope that a better understanding of the cell death biology in the context of cancer will aid the design of new effective therapies. This review will focus on detailing how the apoptotic, necroptotic and autophagic pathways regulate cell viability and we discuss the emerging therapies and strategies targeting these pathways with relevance to cancer.

\section{Apoptosis}

The term 'apoptosis' was introduced by Kerr et al. (1972) to designate a regulated form of cell death with a morphology distinct from that of necrotic cell death (described below). A cell dying via apoptosis is characterised by cell shrinking, nuclear condensation and fragmentation, membrane blebbing and finally separation of the cellular components into apoptotic bodies (Kerr et al., 1972). The redistribution of 


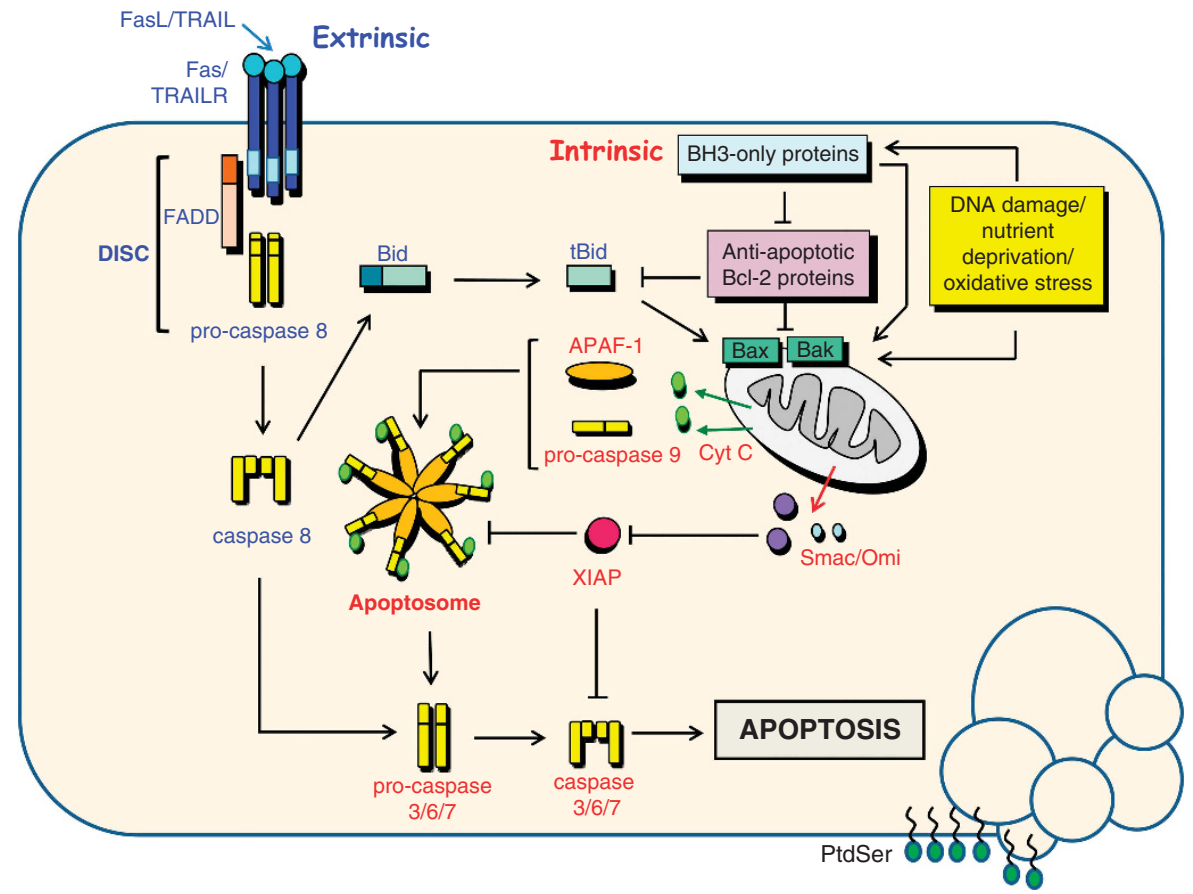

Figure 1 The extrinsic and intrinsic apoptotic pathways. The pathways involved in mediating apoptotic cell death are largely determined by the source of death stimuli. External death cues (for example, immunogenic cytokines) activate the extrinsic pathway whereas the intrinsic pathway is stimulated by internal stress signals (for example, DNA damage, starvation, oxidative stress). Members of the TNF $\alpha$ receptor family are well-established mediators of the extrinsic apoptotic pathway and stimulate apoptosis through death-inducing signalling complex (DISC) assembly and engagement of the caspase cascade. The intrinsic pathway is initiated by the mitochondrial outer membrane permeabilization (MOMP) and release of apoptotic factors such as cytochrome $c$, Smac (also known as DIABLO) and Omi (also known as HtrA2) from the mitochondrial intermembrane space, an event governed by the interactions between pro- and anti-apoptotic proteins of the Bcl-2 family on the mitochondrial surface. Cytochrome $c$ release triggers the formation of the cytochrome $c /$ Apaf-1/caspase- 9 apoptosome, which consequently activates the executioner caspases-3, -6 and/or -7 that cleave different cellular targets to initiate the breakdown of the cell. Smac and Omi promote caspase activity by neutralising XIAP, which attenuates caspases. In certain contexts, the death signal from the extrinsic pathway is amplified by caspase-8-mediated cleavage of Bid, which induces MOMP and downstream activation of executioner caspases.

phosphatidylserine to the extracellular surface is also characteristic of an apoptotic cell, serving as a 'comeand-get-me' signal to attract phagocytes to engulf the fragmented cell (Fadok et al., 1998).

Principally, apoptosis is thought to occur through two main pathways - the intrinsic pathway where the death signal arises from within the cell and the extrinsic pathway, which involves the activation of cell surface receptors by an extracellular death signal-both of which eventually converge in the activation of effector caspases (Degterev et al., 2003) (Figure 1).

\section{Extrinsic pathway}

The extrinsic apoptotic pathway is stimulated by the binding of death ligands of the tumour necrosis factor (TNF) superfamily (TNF, FasL (Fas ligand) and TNFrelated apoptosis-inducing ligand (TRAIL)) to their cognate cell surface death receptors (TNF receptor 1 (TNFR1), Fas, TRAIL receptor 1 (TRAILR1) and TRAILR2) (Walczak and Krammer, 2000; Lavrik et al., 2005; Fulda and Debatin, 2006). Ligand binding to the death receptors promotes receptor trimerisation and clustering of the intracellular cytoplasmic death domains, which recruits various adaptor molecules to form the death-inducing signalling complex (DISC)
(Walczak and Krammer, 2000; Lavrik et al., 2005; Fulda and Debatin, 2006). For Fas, TRAILR1 and TRAILR2 signalling, the DISC comprises FAS-associated death domain (FADD) and pro-caspase-8 whereas the DISC formed downstream of TNFR1 signalling contain additional molecules such as TNFR-associated death domain (TRADD) and TNFR-associated factor 2 (TRAF2) (detailed in Necroptosis section below) (Walczak and Krammer, 2000; Lavrik et al., 2005; Fulda and Debatin, 2006). The cleavage and activation of pro-caspase- 8 following DISC formation subsequently relays the death signal, either by inducing mitochondria outer membrane permeabilisation (MOMP) (see below) or by directly triggering a protease cascade of effector caspases-3, -6 and/or -7 , ultimately committing the cell to die (Scaffidi et al., 1998; Fulda et al., 2002).

\section{Intrinsic pathway}

The intrinsic apoptotic pathway can be triggered by various intracellular stimuli, including DNA damage, growth factor-starvation and oxidative stress (Schmitt and Lowe, 1999; Mayer and Oberbauer, 2003). These insults will stimulate MOMP, causing the leakage of mitochondrial proteins that unleash the apoptotic machinery (Hengartner, 2000; Saelens et al., 2004). 
Upon release from the mitochondria, cytochrome $c$ (cyt $c$ ) promotes Apaf-1 oligomerisation and activation of initiator caspase-9 through the formation of the cyt $c /$ Apaf-1/caspase-9 apoptosome (Cain et al., 2000). The activation of caspase-9 subsequently cleaves and activates executioner caspases-3, -6 and/or -7, which successively cleave a multitude of cellular targets, such as poly (ADP-ribose) polymerase (PARP), inhibitor of caspase-activated DNAse and lamin, that initiates the dismantling of cellular components leading to cell demise (Degterev et al., 2003). Additionally, the concurrent release of second mitochondria-derived activator of caspase (Smac/DIABLO) and OMI/ HTRA2 during MOMP ensures optimal caspase activity is achieved by attenuating the XIAP (X-linked inhibitor of apoptosis protein), which inhibits caspases (Deveraux et al., 1997; Du et al., 2000; Verhagen et al., 2000; Martins et al., 2002).

MOMP is a tightly regulated process, governed by the intricate interactions between pro- and anti-apoptotic members of the B-cell lymphoma 2 (Bcl-2) family (Figure 1) (Chipuk and Green, 2008; Tait and Green, 2010). The Bcl-2 proteins are categorised according to their Bcl-2 homology $(\mathrm{BH})$ domain organisation: (1) effector pro-apoptotic members containing $\mathrm{BH} 1-\mathrm{BH} 3$ domains (Bak, Bax and Bok), which directly execute the MOMP process; (2) anti-apoptotic members containing $\mathrm{BH} 1-\mathrm{BH} 4$ domains (Bcl-2, Bcl-X $\mathrm{L}, \mathrm{Bcl}-\mathrm{w}, \mathrm{mcl}-1$ and A1) that bind and inhibit Bak and Bax and (3) BH3-only proteins (Bid, Bad, Bim, Bik, BNIP3, BMF, HRK, Noxa and Puma) that promote MOMP, either by inhibiting anti-apoptotic Bcl-2 members and thereby de-repressing Bak and Bax, or by directly activating Bak and Bax (Chipuk and Green, 2008; Tait and Green, 2010). In some systems, where death receptor-stimulated DISC formation is low, the death signal is amplified by triggering Bid cleavage and translocation to the mitochondria to activate $\mathrm{Bak} / \mathrm{Bax}$ and induce MOMP (Li et al., 1998; Luo et al., 1998; Scaffidi et al., 1998).

\section{Apoptosis and cancer}

The involvement of apoptosis in cancer was first demonstrated when apoptosis was found to account for the cell death induced during tumour regression in response to radiotherapy (Kerr et al., 1972). However, it was not until the cloning and characterisation of the bcl-2 proto-oncogene that the importance of apoptosis in tumour suppression was truly recognised.

$\mathrm{Bcl}-2$ was first identified as part of the $\mathrm{t}(14: 18)$ chromosome translocation, which leads to enforced expression of Bcl-2, a critical contributing factor to the malignant phenotype of follicular lymphoma cells (Tsujimoto et al., 1984, 1985). The subsequent discovery that the neoplastic properties of $b c l-2$ relied on its ability to prolong B-cell survival (Vaux et al., 1988) revolutionised the cancer oncogene paradigms that were known at that time. Clearly, $b c l-2$ was not a classical transforming oncogene like ras and $c$-myc, which induced hyper-proliferation and prevented differentiation. Instead, oncogenic $b c l-2$ conferred cells the ability to mitigate cell death (Hockenbery et al., 1990), therefore permitting the drive towards neoplasia. The closely related anti-apoptotic $\mathrm{Bcl}-\mathrm{X}_{\mathrm{L}}$ protein has also been found to be upregulated in cancer (Olopade et al., 1997).

Conversely, the reduced expression or mutation of pro-apoptotic Bax/Bak or caspases has been reported in different cancers and correlated with poor clinical prognosis (Rampino et al., 1997; Shivapurkar et al., 2002; Fecker et al., 2006; Ghavami et al., 2009). Nevertheless, it is important to note that the abrogation of apoptotic pathways alone is unlikely to be sufficient to promote tumourigenesis since cancer often arises from a complex interplay of genetic aberrations and deregulated pathways. This was evident in the studies by McDonnell et al. (1989) and McDonnell and Korsmeyer (1991) using a bcl-2-Ig transgenic mouse model to recapitulate the $\mathrm{t}(14: 18)$ chromosome translocation found in follicular lymphoma. Although the mice exhibited sustained B-cell survival and lymphoid hyperplasia, the incidence of tumours in these mice was surprisingly low and developed only after a long latency period (McDonnell and Korsmeyer, 1991). More importantly, in the subset of mice that eventually developed high-grade lymphomas, the translocation of the $m y c$ gene was also detected implicating the need for additional genetic alterations to enable malignant progression (McDonnell and Korsmeyer, 1991). Indeed, a sequential rearrangement of $b c l-2$ and $m y c$ has been observed in the progression of non-Hodgkin's lymphoma (Lee et al., 1989) and various studies have demonstrated a co-operation between $m y c$ and $b c l-2 / b c l-X_{L}$ (Vaux et al., 1988; Fanidi et al., 1992; Cheung et al., 2004) in promoting cancer cell proliferation and tumour growth.

\section{Necrosis and necroptosis}

Distinct from apoptosis, necrosis is morphologically characterised by an early onset plasma membrane permeabilisation, which causes cells to swell and finally rupture, spilling their intracellular contents into the extracellular milieu (Vandenabeele et al., 2010). In many cases, necrosis is also accompanied by lysosomal membrane disintegration and release of lysosomal hydrolases, which help catalyse the breakdown of the cell (Artal-Sanz et al., 2006; Boya and Kroemer, 2008). Unlike apoptotic cells, the nuclei of necrotic cells remain largely intact (Vandenabeele et al., 2010).

For many years, necrosis was stereotyped as being a form of death occurring in an unregulated manner, resulting from severe insults or adverse conditions. However, a regulated form of necrosis was implicated in studies, demonstrating that classical death receptors could induce necrosis upon inhibition of apoptosis by the caspase inhibitor, zVAD-fmk (Vercammen et al., 1998a) and that this novel form of necrosis was mediated by kinases of the receptor interacting protein (RIP) family, RIP1 and RIP3 (Holler et al., 2000; He et al., 2009; Zhang et al., 2009). Subsequently, necrostatin-1 was discovered as a potent inhibitor of this specific type of programmed necrosis, which was given the name 'necroptosis' (Degterev et al., 2005). Since 


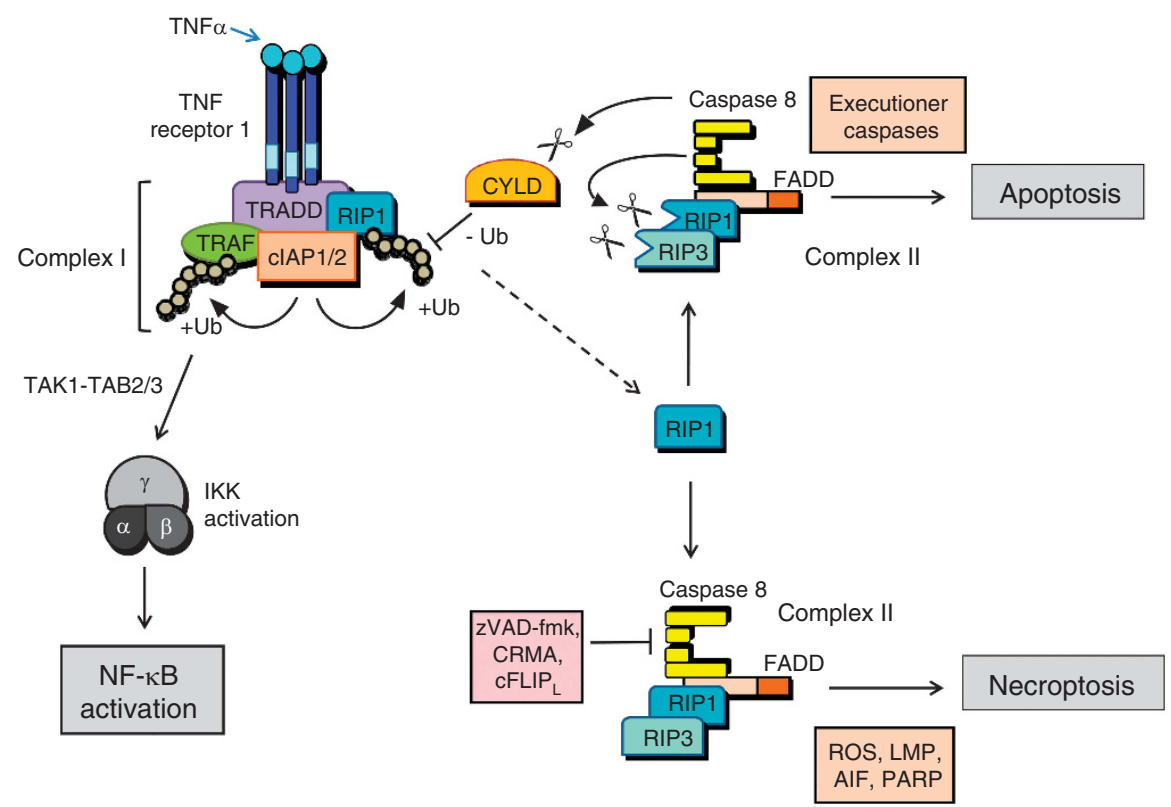

Figure 2 TNF $\alpha$ receptor-mediated activation of apoptosis and necroptosis. TNF activation of its receptor promotes the formation of complex I (containing signalling molecules TRADD, TRAF2, cIAP1, cIAP2 and RIP1). Polyubiquitination of RIP1 by cIAP1 and cIAP2 enables the interaction of RIP1 with the TAK-1 (TGF (transforming growth factor)- $\beta$-activated kinase 1)/TAB2 (TAK-1 binding protein 2)/3 complex, which activates the IKK complex and NF- $\kappa$ B pathway. As a negative feedback mechanism, RIP1 can be deubiquitinated by CYLD, and subsequently form a complex with RIP3, TRADD, FADD and caspase-8 (complex II). Complex II normally proceeds to initiate the apoptotic machinery and this is accompanied by caspase-8-dependent cleavage of RIP1 and RIP3. If, however, caspase-8 activity is blocked (for example, by zVAD-fmk, CrmA or cFLIP), RIP1 and RIP3 cleavage is prevented and the kinases can signal to the necroptotic machinery to trigger non-apoptotic cell death. The execution of necroptosis has been shown to involve ROS, lysosomal membrane permeabilisation (LMP) apoptosis-inducing factor (AIF) and PARP.

then, numerous studies have contributed to the significant advancement in understanding the mechanism of necroptosis.

\section{TNFR1 induction of necroptosis}

The activation of numerous death receptors has been linked to necroptosis induction (Holler et al., 2000; Ch'en et al., 2011) although the TNFR1-mediated necroptotic pathway is the most extensively studied. The signalling pathway by which the TNFR1 stimulates necroptosis has been elegantly reviewed by Vandenabeele et al. (2010). Therefore, this review will only give a brief overview of the TNFR1-mediated necroptotic pathway.

A fascinatingly pleiotropic receptor, TNFR1 is known to regulate cell survival, inflammation, apoptosis and necroptosis, depending on the coupling to different downstream signalling pathways (Figure 2). Upon TNF binding, TNFR1 undergoes a conformational change that allows the recruitment of various signalling molecules such as TRADD, TRAF2, cellular inhibitor of apoptosis 1 (cIAP1), cIAP2 and RIP1, to form a complex referred to as complex $I$ (Micheau and Tschopp, 2003; Vandenabeele et al., 2010). cIAP1 and cIAP2, both E3 ligases, causes the polyubiquitylation of proteins in complex I, including RIP1, which serves as a platform to dock additional signalling molecules (that is, the IKK complex) that proceed to activate the nuclear factor (NF)-kB survival or inflammatory pathways
(Devin et al., 2000; Bertrand et al., 2008; Bianchi and Meier, 2009).

RIP1 can subsequently be deubiquitylated by the enzyme, cylindromatosis (CYLD) (Wright et al., 2007), and together with RIP3, form a complex containing TRADD, FADD and caspase-8, called complex II (Micheau and Tschopp, 2003). The formation of complex II initiates the cell death signal and the decision between death via apoptosis or necroptosis is determined at this step. Caspase-8-mediated cleavage of RIP1 and RIP3 will trigger the caspase cascade and induce apoptosis (Lin et al., 1999), whereas the inhibition of caspase-8 (by zVAD-fmk, CrmA or $\mathrm{cFLIP}_{\mathrm{L}}$ ) or knockout of FADD will abrogate the apoptotic signal to favour necroptosis (Holler et al., 2000; Cho et al., 2009b; Zhang et al., 2011). Recently, O'Donnell et al. (2011) reported caspase-8 to also cleave CYLD, preventing the deubiquitylation of RIP1 and thereby, necroptosis.

The exact mechanism by which RIP1-RIP3 enforces necroptosis remains to be elucidated although the involvement of ROS (reactive oxygen species) production, lysosomal membrane permeabilisation, apoptosisinducing factor and PARP has been implicated (Vercammen et al., 1998b; Lin et al., 2004; Vandenabeele et al., 2010; Delavallee et al., 2011).

\section{Necrosis and necroptosis in cancer}

Necrosis arising from chemotherapy treatment is not uncommon and accounts for cell death observed in apoptosis-defective tumour cells (Zong et al., 2004). 
In these circumstances, induction of necrosis may have the added benefit of invoking the host's innate immune response to aid tumour cell death and clearance (Amaravadi and Thompson, 2007).

The identification of necroptosis as an alternative form of programmed cell death is particularly exciting in the context of cancer treatment since it involves a highly specialised pathway that allows specific drug targeting. Little has been reported about the role of necroptosis in cancer but several studies have advocated a possible link between necroptosis and tumour suppression.

Animal studies have reported that mice lacking CYLD exhibited an increased susceptibility to carcinogen-induced skin tumours and inflammation-induced colonic tumours (Massoumi et al., 2006; Zhang et al., 2006). While the studies concluded that the tumour suppressive action of CYLD may arise from the inhibition of the pro-survival and pro-inflammatory $\mathrm{NF}-\kappa \mathrm{B}$ pathways, it is possible that CYLD-dependent apoptosis or necroptosis may also curb tumourigenesis. This certainly warrants further investigations.

Additionally, RIP3- and caspase-8-double knockout mice exhibit enlarged spleens and lymph nodes and an abnormal accumulation of $\mathrm{T}$ cells in secondary lymphoid tissues (Kaiser et al., 2011; Oberst et al., 2011). A marked increase in T-cell numbers was also observed in RIP1- and FADD-double knockout chimaeras (Zhang et al., 2011), suggesting that a hyper-proliferative disorder can occur when components of necroptosis signalling are altered. Furthermore, the truncated splice variant of RIP3, RIP3 $\gamma$, has been reported to be upregulated in cancer tissues (Yang et al., 2005). In vitro, RIP3 $\gamma$ acts in a dominant negative manner to attenuate full-length RIP3-mediated cell death, again implying that defective necroptosis may account for cancer progression. Further studies are essential to fully understand the link between necroptosis and cancer suppression in order to explore the potential of manipulating necroptosis as a novel anti-cancer strategy.

\section{Autophagy}

The ability of cells to digest their own cellular components was first observed by Christian de Duve, who subsequently introduced the term 'autophagy' to describe the process (Yang and Klionsky, 2010). Three forms of autophagy have been characterised-macroautophagy, microautophagy and chaperone-mediated autophagy (Mizushima et al., 2008). Macroautophagy and chaperone-mediated autophagy have both been shown to be important in cancer with macroautophagy (hereafter referred to as autophagy) being the most extensively studied to date (Mizushima et al., 2008). It is now known that autophagy is an important housekeeping process for degrading and recycling long-lived proteins, cellular aggregates and damaged organelles (Yang and Klionsky, 2010). Additionally, several studies have found autophagy to be enhanced in liver of starved animals in response to glucagon or amino-acid deprivation (Novikoff et al., 1964; Deter et al., 1967; Mortimore and Schworer, 1977), demonstrating a self-preservation role for autophagy during nutrient-starvation.

Autophagy begins with the formation of an isolation membrane or phagophore that elongates to form a double-membrane-bound vesicle termed an autophagosome, enveloping cytoplasmic cargoes targeted for degradation (Mizushima et al., 2002) (Figure 3). During autophagosome formation, a cytoplasmic protein, LC3-B, undergoes lipidation and is recruited to the nascent autophagosome membrane. The accumulation of LC3-B in autophagosomes can be visualised as distinct puncta under the microscope, and is often used as a marker for autophagy (Kabeya et al., 2000). In some cases, autophagy cargoes are delivered to autophagosomes by specific adaptor proteins that interact with LC3-B, such as NBR1 and p62/SQSTM1 (Pankiv et al., 2007; Kirkin et al., 2009). Autophagosomes subsequently fuse with lysosomes, forming an autolysosome where the autophagosome contents are broken down by acidic hydrolases provided by the lysosome (Mizushima et al., 2002). The catabolic products are then either recycled into the biosynthetic pathways or undergo further degradation to yield energy. Although autophagy occurs continuously at basal levels in most, if not all, cells, the rate and composition of autophagic cargoes can be regulated as and when required. Autophagy is tightly regulated by a subset of genes called the autophagyrelated genes $(A T G)$, which are described in detail in our previous review (Rosenfeldt and Ryan, 2011).

\section{Autophagy - an alternative cell death mechanism?}

The role of autophagy as an alternative cell death mechanism has, in recent years, been a topic of debate. It was the manifestation of autophagosomes in dying cells exhibiting features distinct from apoptosis that led scientists to suggest a death-promoting role for autophagy (Levine and Yuan, 2005). In vitro studies found the abrogation of autophagy by 3-methyladenine (Schwarze and Seglen, 1985; Azad et al., 2008) or knockdown of autophagy-related genes, beclin 1 and $\operatorname{atg} 5$ or $\operatorname{atg} 7$, (Shimizu et al., 2004; Yu et al., 2004) prevented cell death. In vivo, chemotherapy and radiotherapy are known to induce both cell death and autophagy in tumour cells, and autophagy has been observed to confer a tumour suppressive effect in various animal models (see subsequent section). Additionally, autophagy has been shown to be required for the cell death observed during Drosophila salivary gland development (Berry and Baehrecke, 2007).

However, although accumulation of autophagosomes is frequently observed in dying cells following exposure to anti-cancer treatments, this may well be an adaptive survival response to counteract death, and the antitumour functions of autophagy in animal models could arise from non-cell death-related effects of autophagy (detailed below). Some studies have also found the inhibition of autophagy failed to reverse starvationmediated death (Kosta et al., 2004) and that autophagy even promotes tumour cell survival and resistance to myc-/p53-induced apoptosis (Degenhardt et al., 2006; Amaravadi et al., 2007). Furthermore, Kroemer and 


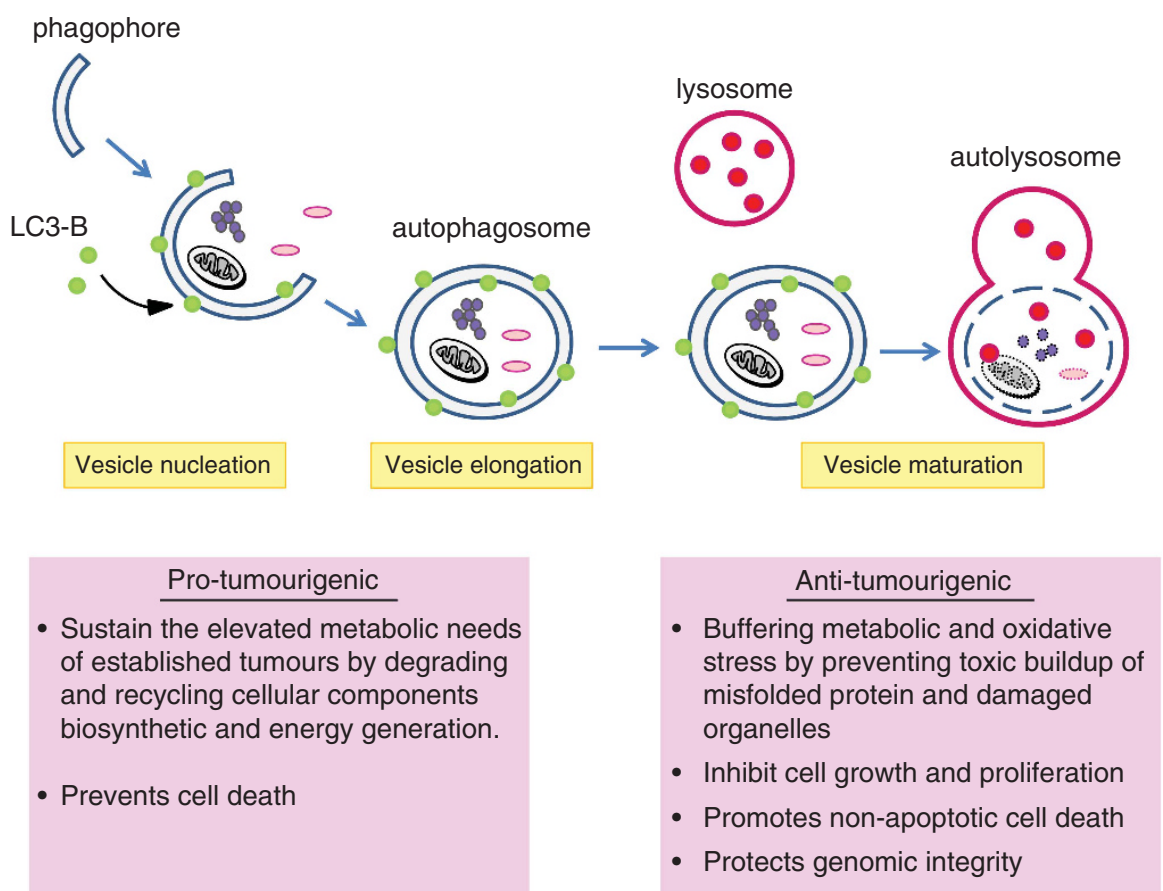

Figure 3 The mechanism and paradoxical role of autophagy in cancer. Autophagy commences with the encapsulation of cytoplasmic material, damaged proteins or organelles by an isolation membrane or phagophore (vesicle nucleation). The phagophore elongates until the ends of the phagophore fuses to form a double-membrane vesicle, an autophagosome, sequestering the autophagic cargoes destined for degradation (vesicle elongation). Concomitantly, LC3-B undergoes lipidation and is recruited to the autophagosomal membrane to assist vesicle elongation. The outer membrane of the autophagosome subsequently fuses with the lysosome, forming an autolysosome (vesicle maturation) and the contents of the autophagosome are broken down by lysosomal hydrolases. Autophagy has been shown to be both pro- and anti-tumourigenic through the different actions listed above.

colleagues recently conducted a screen involving 1377 cytotoxic compounds and found that none of the compounds induce cell death by autophagy (Shen et al., 2011).

Therefore, caution should be exercised when describing the involvement of autophagy in cell death since there is still no concrete evidence showing that autophagy directly executes cell death. Specifically, the use of the phrase 'autophagic cell death' is now deemed inaccurate and the Nomenclature Committee of Cell Death 2009 has advised the use of the term 'cell death with autophagy' as a more appropriate reference to cell death connected to autophagy (Galluzzi et al., 2009).

The role of autophagy in cancer-a double-aged sword Similar to the paradoxical involvement of autophagy in cell death, the role of autophagy in cancer is controversial. While some studies have suggested a tumour suppressive role for autophagy, for example, the tumour-prone nature of autophagy-compromised mice (Beclin $1+/-$, ATG4C $-/-$ and Bif $1-/-$ mice, mice with liver-specific ATG7-deletion or mosaic deletion of ATG5) (Qu et al., 2003; Yue et al., 2003; Marino et al., 2007; Takahashi et al., 2007; Takamura et al., 2011) and the inactivation of autophagy genes in certain human cancers (Liang et al., 1999; Miracco et al., 2007; Kang et al., 2009), other studies have shown the opposite, for example, Yang et al. (2011) and Guo et al. (2011) found tumour cells to exhibit high basal levels of autophagy that is required for cancer cell proliferation.

It has been suggested that the polarity between the pro-tumourigenic and anti-tumourigenic role of autophagy may be tumour stage dependent (Rosenfeldt and Ryan, 2009). Autophagy is potentially tumour suppressive at the initial stages of cancer development by preventing the toxic buildup of misfolded proteins and damaged organelles, which if persist, can increase oxidative stress, promote genomic instability and predispose cells to malignant transformation. Certainly, Mathew et al. $(2007,2009)$ reported autophagy deficiency to induce an aberrant accumulation of the autophagy adaptor protein p62, increased ROS levels, abnormal gene amplification, DNA damage and aneuploidy. Cells lacking atg5 and overexpressing p62 exhibited a significantly higher tumourigenic potential compared with atg5-deficient cells overexpressing the control vector in xenograft studies (Mathew et al., 2009). Additionally, the ability of autophagic proteins, Beclin 1, Ambra 1, UVRAG and Bif-1, to inhibit cell proliferation, promote non-apoptotic cell death and regulate endocytosis (Liang et al., 1999, 2006; Qu et al., 2003; Yu et al., 2004; Fimia et al., 2007; Koneri et al., 2007; Takahashi et al., 2007; Matsunaga et al., 2009) may also contribute to their tumour suppressive effects.

Nevertheless, if healthy cells fail to maintain proteome and genome integrity and progress on to develop cancer, autophagy may subsequently switch to confer a 
tumour-promoting role by supplementing the metabolic needs of growing tumours in nutrient- and oxygendeprived conditions. Indeed, studies by Yang et al. (2011) and Guo et al. (2011) demonstrated the inhibition of autophagy to cause tumour regression and prolong survival of mice in xenograft studies. This correlated with an impediment of mitochondrial respiration and energy production, advocating the reliance of cancer cells on autophagy-dependent energy regeneration to sustain tumour growth.

\section{p53 regulation of apoptosis and autophagy}

The ability of p53 to induce apoptosis constitutes one of the many ways the tumour suppressor protein prevents cancer development. p53 promotes apoptosis by transcriptionally activating genes encoding death receptors Fas and DR5 (Muller et al., 1998; Takimoto and El-Deiry, 2000) and pro-apoptotic proteins Bax, Bid, Noxa and Puma (Yin et al., 1997; Oda et al., 2000; Nakano and Vousden, 2001; Sax et al., 2002; Thornborrow et al., 2002), or by repressing anti-apoptotic bcl-2 transcription ( $\mathrm{Wu}$ et al., 2001). Some studies have also reported $\mathrm{p} 53$ to localise to the mitochondria and directly engage the apoptotic machinery to induce cell death (Mihara et al., 2003; Leu et al., 2004; Chipuk et al., 2005).

The role for p53-mediated autophagy as a means of tumour prevention has also been reported. Our group previously identified DRAM-1, as a novel transcriptional target of p53 that induces autophagy and is required for p53-dependent apoptosis (Crighton et al., 2006). On the other hand, Tasdemir et al. (2008) found basal levels of p53 to suppress autophagy, by regulating the mammalian target of rapamycin (mTOR) pathway in a manner independent of p53 transcriptional activity. The inactivation of $\mathrm{p} 53$ was found to de-repress autophagy and promote resistance to metabolic stress. Therefore, p53-mediated regulation of autophagy as a tumour suppressive mechanism may function at two levels - (1) at basal level, cytoplasmic p53 limits the cytoprotective functions of autophagy that drives tumour cell survival and (2) when stimulated by cellular stress, p53 transcriptional induction of DRAM-1 induces autophagy and facilitates tumour cell death.

\section{Interplay between apoptosis, necrosis/necroptosis and autophagy}

Despite the remarkable progress in the classification of the different cell death modes according to the morphological presentation, signalling pathways and type of stimuli, cell death in vivo often comprises a complex interplay between apoptosis, necrosis/necroptosis and autophagy (Figure 4). Apoptosis, necrosis/ necroptosis and autophagy can all occur independent of, or simultaneously with, each other. In some situations, a specific stimulus evokes only one of the processes but in other situations, a combined cell death phenotype is observed in response to the same stimulus (Samara

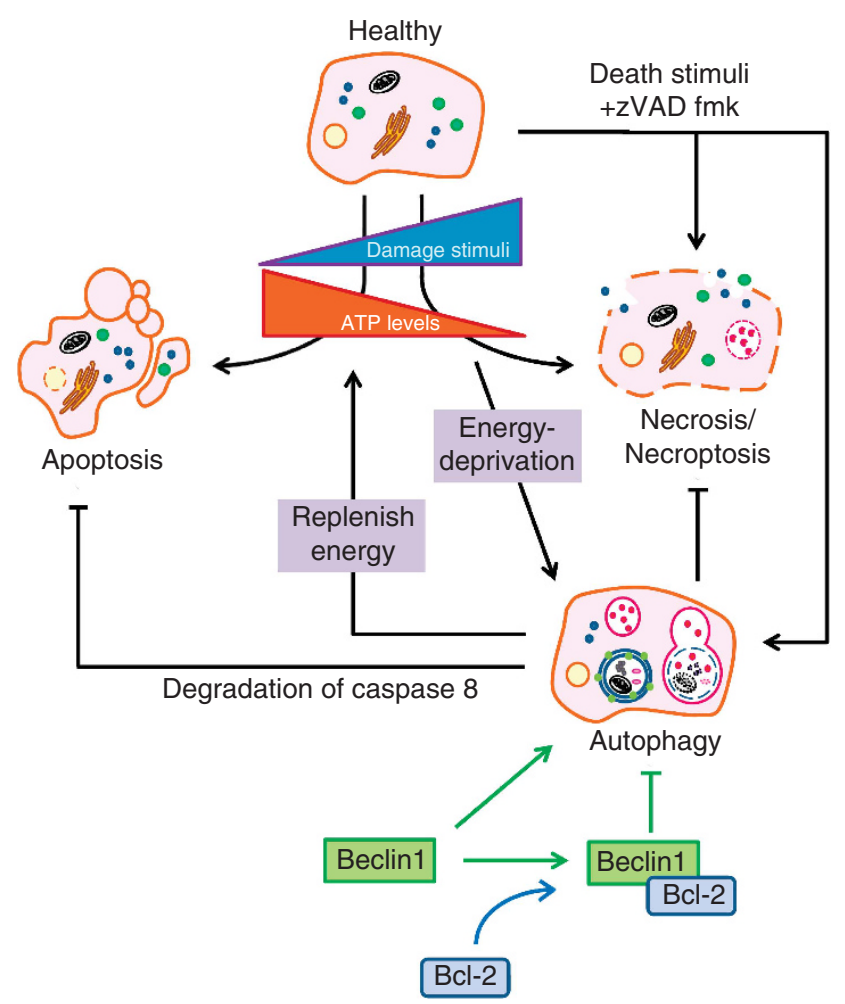

Figure 4 The interplay between apoptosis, necrosis/necroptosis and autophagy. The decision taken by a cell to undergo apoptosis, necrosis/necroptosis or autophagy is governed by various factors including energy/ATP availability, amplitude of damage or stress and the presence of inhibitors of the specific pathways (e.g., caspase inhibitor zVAD-fmk). A depletion in ATP levels often stimulates autophagy to sustain cell viability and prevent necrosis, but if autophagy fails to maintain sufficient levels of ATP, necrosis ensues. Cell death via apoptosis, on the other hand, is usually triggered in conditions where there is sufficient ATP availability to fuel the activity of caspases. In terms of the severity of damage and stress encountered by cells, high levels of the death signals often result in necrosis whereas lower levels stimulate apoptosis. It has also been the general consensus that apoptosis is often the first choice mode of cell death and that only upon inhibition of the apoptotic machinery that necrosis/necroptosis prevails, although emerging evidence suggests that the necroptotic pathway may predominate in certain situations. Autophagy may also be induced upon inhibition of apoptosis, either to counteract necrosis/ necroptosis or to coordinate with necrosis/necroptosis to promote cell death. Apoptosis has been shown to regulate autophagy through Bcl-2-mediated sequestration or caspase-dependent cleavage of Beclin 1 but autophagy was recently reported to impede apoptosis by degrading caspase-8. Clearly, the interrelationship between apoptosis, necrosis/necroptosis and autophagy is extremely complex and the choice of route taken by a cell will vary under different circumstances.

et al., 2008; Bellot et al., 2009). In other instances, a particular pathway may predominate over others, which are only activated if the dominant pathway is attenuated. This is further complicated by the fact that autophagy can serve both a pro-survival and pro-death function.

Hence, the pertinent question is what determines the choice of route taken to eliminate a cell when the cell's death fate has been decided? Which pathways will predominate and under what circumstances? 
Energy requirement determines the road to ruins

The bioenergetic consumption within a dying cell has been postulated to influence the path of death taken to eradicate the cell. Studies examining the consumption of ATP during apoptosis found ATP depletion to prevent apoptosis and induce necrosis (Eguchi et al., 1997; Leist et al., 1997). Apoptosis consumes high energy since the activation of caspases and formation of the apoptosome require ATP (Eguchi et al., 1997; Salvesen and Renatus, 2002). This explains why caspases preferentially terminate other ATP-consuming processes such as PARP activity (Soldani and Scovassi, 2002) and protein translation (Salvesen and Renatus, 2002), in order to conserve energy to ensure completion of apoptosis. The opposite occurs during necrosis/necroptosis, as PARP activity and protein translation persists (Leist et al., 1997). In fact, PARP activity is often stimulated during necroptosis (Vandenabeele et al., 2010), possibly as an attempt to exhaust energy storage to drive necroptosis. RIP1 has been linked to ATP depletion by inhibiting ATP synthase during necroptosis (Temkin et al., 2006). Interestingly, Leist et al. (1997) demonstrated that the replenishment of glucose in ATP-depleted $\mathrm{T}$ cells prevents necrotic death and promotes cells to die via apoptosis, suggesting that by manipulating ATP levels, cells can be 'instructed' to die by either apoptosis or necrosis/necroptosis.

As mentioned before, autophagy is regulated by energy availability within the cell. Autophagy is often activated as an adaptive response to ATP depletion to replenish energy reserves to help counteract necrosis/ necroptosis (Lum et al., 2005; Amaravadi and Thompson, 2007; Wu et al., 2008). Likewise, the inhibition of autophagy can trigger a bioenergetic crisis, promoting necroptosis (Degenhardt et al., 2006). Nevertheless, autophagy can also be stimulated in parallel with necroptosis to enhance cell death. For example, Yu et al. (2004) reported that inhibition of apoptosis by zVAD-fmk induced both necroptosis and autophagy, and the resulting death could be reversed by downregulating RIP1, Beclin 1 and ATG7. The pro-death effect of autophagy in this context is unlikely related to energy expenditure but is associated with the necroptotic pathway, suggesting that energy requirement represents only one of the many factors influencing the mode of cell death.

\section{When more or less counts}

The choice of pathways that may or may not be induced by a signalling cue also implies the existence of variable effective thresholds within each pathway that have to be achieved in order for successful execution. It has been reported that varying levels of caspase-3 activity can influence the susceptibility of breast and lung cancer cells to paclitaxel-triggered death (Odonkor and Achilefu, 2008). Upon paclitaxel treatment, cancer cells with lower basal and weaker fold of induction of caspase-3 activity appeared to be more resilient to death compared to cells with higher basal and greater induction of caspase-3. Another study observed the basal activity of caspase-3 to promote invasiveness of glioma cells in the absence of death (Gdynia et al., 2007). These findings advocate that basal or low levels of caspase-3 are insufficient to engage the cell death pathways because of the failure to reach an effective threshold. It is possible that a functional threshold is present in other signalling molecules governing the activation of cell death pathways.

The intensity of a death stimulus is also critical in influencing cellular outcome. Cisplatin was observed to induce apoptosis at low doses, but necrosis at high doses in mouse renal epithelial cells (Lieberthal et al., 1996). This was similarly observed for cyclosporin (Healy et al., 1998). In addition, low levels of DNA damage favours p53 to induce cell-cycle arrest, as an attempt to allow cells a chance to repair the damage and survive. However, high levels of DNA damage induce p53mediated apoptosis, as the damage is deemed irreparable and the replication of such cells is potentially harmful to the organism ( $\mathrm{Li}$ and Ho, 1998). Furthermore, a weak and sustained p53 signal has been shown to promote senescence whereas strong activation of $\mathrm{p} 53$ induced apoptosis (Leontieva et al., 2010).

\section{Is necroptosis just a backup suicide route when apoptosis} fails?

The physiological relevance of necroptosis has been a common debate since its discovery because the phenomenon is usually observed only upon pharmacologic (zVAD-fmk) or genetic (Apaf-1 or FADD knockout) inhibition of the apoptotic pathway (Shiraishi et al., 2010; Wu et al., 2011; Zhang et al., 2011). This apparent overshadowing of necroptosis by apoptosis implies that apoptotic death is the first choice in most settings and that necroptosis acts only as a safeguard alternative to ensure cell demise is inevitable should the apoptotic machinery fail. A study by Chautan et al. (1999), looking at interdigital cell death during limb development in mice, found this to be the case. The study showed that while interdigital cell death normally occurred via apoptosis, treatment of limb buds with zVAD-fmk caused cells to die by necrosis instead. In agreement, Apaf-1-/- or 'hammertoe' mutant mice, with a hereditary condition of reduced apoptosis of interdigital spaces, exhibited good separation of limb digits despite the defect in apoptosis. A closer inspection of the interdigital cells from these mice showed that the cells were predominantly necrotic, suggesting that necrosis can compensate for the lack of apoptosis, when required.

Contrariwise, Chan et al. (2003) demonstrated a biological context in which necroptosis predominates. The authors found that vaccinia virus infection can promote TNFR2-mediated necroptotic death in response to TNF. The knockdown of TNFR2 in mice was observed to substantially reduce the clearance of vaccinia virus and viral-induced inflammation, suggesting an antiviral function of TNFR2-facilitated necroptosis. Importantly, the study shows that necroptosis may not merely function as a backup suicide mechanism 

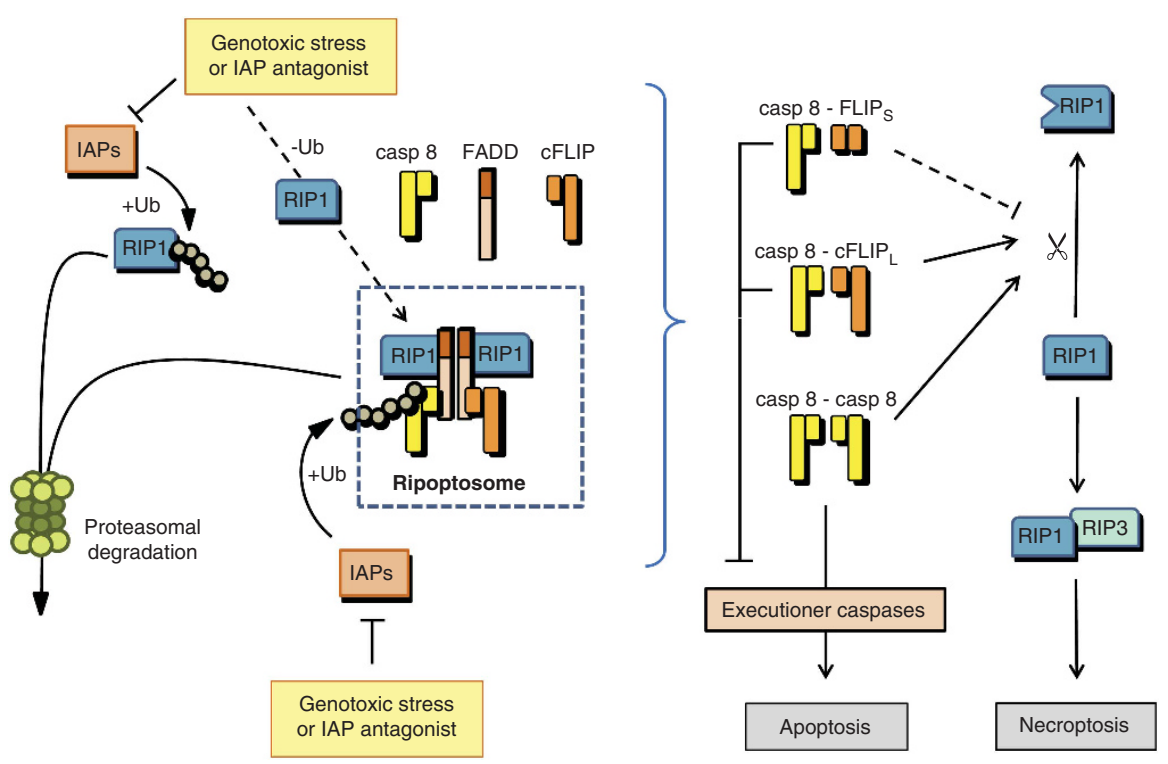

Figure 5 IAP and cFLIP regulation of the ripoptosome signalling complex. Under basal conditions, IAPs constitutively target RIP1 for proteasomal degradation. The depletion or inhibition of IAPs caused by genotoxic stress or IAP antagonists prevents RIP1 degradation and stimulates formation of the ripoptosome complex, containing caspase-8, FADD, RIP1 and cFLIP, independently of cell surface receptor activation. IAPs can also directly inactivate ripoptosome signalling by targeting components of the complex for proteasomal degradation. The composition of the ripoptosome complex is crucial in determining cellular outcome. Caspase-8homodimers within the ripoptosome activates downstream caspases to stimulate the apoptotic pathway. Although the caspase-8$\operatorname{cFLIP}_{\mathrm{L}}$ heterodimers lack the ability to activate the apoptotic pathway, the heterodimers retain sufficient activity to cleave RIP1 and

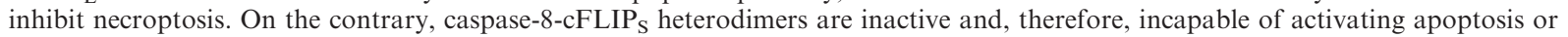
cleaving RIP1. This consequently leads to necroptosis.

secondary to apoptosis, but may actually play a key role in immune defence against infections. Certainly in relation to cancer, infections by cancer-related viruses such as the human papilloma virus are known to paralyse apoptotic pathways and prevent cell death. The possibility that the necroptotic pathway may still be intact in these circumstances suggests that the exploitation of this alternative cell death pathway may help kill apoptotic-resistant cancer cells.

\section{Ripoptosome - a novel death-regulating complex}

Emerging evidence has suggested that apoptosis and necroptosis can be regulated by a newly defined RIP1, FADD and caspase- 8 signalling platform termed the 'ripoptosome', which assembles in response to IAP inhibition by genotoxic stress or pharmacological agents (Figure 5) (Feoktistova et al., 2011; Tenev et al., 2011). Unlike complex II, the ripoptosome does not originate from or require death receptor activation for assembly. Instead, ripoptosome assembly and cellular outcome is tightly regulated by IAPs and isoforms of cellular FLICE-like inhibitory protein (cFLIP), a catalytically inactive homologue of caspase-8.

Under basal conditions, IAPs constitutively stimulate ubiquitylation and targeting of RIP1 for proteasomal degradation. However, the depletion of IAPs, that is, during genotoxic stress or Smac-mimetic treatments, derepresses RIP1 and allows its binding to FADD and caspase- 8 to form the ripoptosome. The complex subsequently signals to downstream apoptotic and necroptotic pathways depending on the differential regulation of caspase- 8 activity by cFLIP (Feoktistova et al., 2011; Tenev et al., 2011). In the absence of cFLIP, the ripoptosome signals to the apoptotic pathway. On the other hand, expression of the long isoform of cFLIP $\left(\mathrm{cFLIP}_{\mathrm{L}}\right)$, which binds caspase-8, neutralises the ability of caspase- 8 to activate the apoptotic machinery. Although $\mathrm{cFLIP}_{\mathrm{L}}$ suppresses the ability of caspase- 8 to induce cell death, binding of $\mathrm{cFLIP}_{\mathrm{L}}$ to caspase-8 actually promotes localised activation of caspase- 8 . This cFLIP $_{\mathrm{L}}$-caspase- 8 heteromer cleaves RIPK1 and prevents RIPK1-RIPK3 association (Micheau et al., 2002; Oberst et al., 2011). cFLIP $\mathrm{L}_{\mathrm{L}}$ therefore, inhibits necroptosis as well as apoptosis. In contrast, the short isoform of cFLIP ( cFLIP $_{S}$ ), while able to bind to caspase-8, does not form an active heteromer. The cFLIP $_{\mathrm{S}}$-caspase-8 heterodimer is unable to catalyse RIPK 1 cleavage or impede RIPK1-RIPK3 association, and hence, stimulates necroptosis (Feoktistova et al., 2011). From a therapeutic perspective, the ripoptosome represents a novel vantage point to trigger tumour cell death. Further understanding of ripoptosome signal regulation is therefore essential for potential manipulation of the pathway for cancer therapy.

\section{The Beclin 1- Bcl-2 switch}

The identification of Beclin 1 as a $\mathrm{BH} 3$-only protein that can interact with $\mathrm{Bcl}-2$ and $\mathrm{Bcl}-\mathrm{X}_{\mathrm{L}}$, marked an exciting point of convergence between the autophagic and the apoptotic machinery (Liang et al., 1998; Maiuri et al., 2007b). Pattingre et al. (2005) and Maiuri et al. (2007a) demonstrated that $\mathrm{Bcl}-2 / \mathrm{Bcl}-\mathrm{X}_{\mathrm{L}}$ functions as an 
important regulator of autophagy by binding and antagonising Beclin 1 . The ability of $\mathrm{Bcl}-2 / \mathrm{Bcl}-\mathrm{X}_{\mathrm{L}}$ to inhibit Beclin 1 is thought to help maintain basal levels of autophagy at a safe, physiological range, to avoid uncontrolled cellular degradation. However, only the endoplasmic reticulum (ER), but not the mitochondrial, pool of $\mathrm{Bcl}-2 / \mathrm{Bcl}-\mathrm{X}_{\mathrm{L}}$ is thought to attenuate autophagy, suggesting a spatial separation of $\mathrm{Bcl}-2 / \mathrm{Bcl}-\mathrm{X}_{\mathrm{L}}$ function between autophagy inhibition at the ER and apoptosis abrogation at the mitochondria (Pattingre et al., 2005; Maiuri et al., 2007a).

The apoptotic pathway has also been shown to hinder autophagy by caspase-mediated cleavage of Beclin 1 (Cho et al., 2009a; Djavaheri-Mergny et al., 2010; Luo and Rubinsztein, 2010). This is thought to block the cytoprotective function of autophagy while amplifying the apoptotic signal.

Although Beclin 1 does not regulate Bcl-2 function or apoptosis (Ciechomska et al., 2009), autophagy has been found to promote the degradation of caspase- 8 and switch off the apoptotic pathway (Hou et al., 2010), suggesting that crosstalk between the two pathways can, in fact, occur in both directions.

\section{Current therapeutic advances in cancer treatment}

In addition to inhibiting the proliferative machinery and pro-survival oncogenic signals of tumours, current anticancer strategies are also attempting to reactivate tumour cell death pathways to induce cancer regression. The revival of inactivated cell death pathways in cancer has previously been mostly unsuccessful, but current advances in this field are showing good potential. There has recently been a surge of promising cancer therapies that specifically target cell death pathways and autophagy, and are effective at killing tumour cells. The following section of the review describes some of the therapies that are currently being tested in clinical trials, and discusses the approaches behind the use of these drugs to treat cancer.

\section{BH3 mimetics}

ABT-737 and its orally active derivative, ABT-263, are 'BH3-mimetic' drugs that inhibit $\mathrm{Bcl}-2, \mathrm{Bcl}-\mathrm{X}_{\mathrm{L}}$ and Bcl-w to liberate Bax and Bak, which are subsequently free to induce apoptosis (Oltersdorf et al., 2005). ABT737 is ineffective at killing cells lacking both Bak and Bax, showing that the mode of action is exclusive to the mitochondrial apoptosis pathway.

ABT-737 was effective as a single agent in killing small cell lung cancer (SCLC) cells and lymphomas in vitro, and promoted SCLC tumour regression and enhanced survival of mice (Oltersdorf et al., 2005). ABT-263 is currently in phase I and II clinical trials as a single agent for treatment of SCLC and haematological malignancies that overexpress Bcl-2 (Cragg et al., 2009). In vitro, $\mathrm{ABT}-737$ has also been reported to synergise with conventional chemotherapy, $\gamma$-irradiation and tyrosine kinase inhibitors, imatinib and gefitinib to reverse drug resistance and kill cancer cells (Cragg et al., 2009). Interestingly, imatinib- and gefitinib-induced death requires the upregulation of $\mathrm{BH} 3$-only proapoptotic protein, Bim (Kuroda et al., 2006; Cragg et al., 2007). It is likely that the synergistic death achieved by tyrosine kinase inhibitor co-treatment with ABT-737 is caused by ABT-737 liberation of Bim, which has been observed by Cragg et al. (2008). The testing of ABT-263 in combination therapies in clinical trials will be the next step forward.

\section{TRAIL}

TRAIL emerged as a prospective anti-cancer drug when cancer biologists recognised the ability of TRAIL to induce apoptosis in malignant cells with negligible effects on non-malignant cells. The cancer-specific effect is thought to occur because the DcR1 and DcR2 decoy receptors, which often neutralise signalling of TNFR family members, are expressed more frequently in normal tissues than in cancer cells (Ashkenazi and Dixit, 1998). Furthermore, unlike TNF and FasL, TRAIL only weakly stimulates the pro-survival $\mathrm{NF}-\kappa \mathrm{B}$ pathway.

In pre-clinical studies, the co-administration of TRAIL with chemotherapeutic agents, irradiation, Akt inhibitors or proteasome inhibitors sensitised TRAIL-resistant tumours to cell death (Hetschko et al., 2008; Pavet et al., 2011). The mechanism of sensitisation was unclear but proteasomal inhibitors have been shown to prime tumour cells to die in response to TRAIL by upregulating the DR5 receptor or promoting DISC formation (Koschny et al., 2007; Hetschko et al., 2008). In clinical trials, however, TRAIL was disappointingly found to provide no added benefit when given in combination with existing chemotherapy treatment to an unselected group of non-small cell lung cancer (NSCLC) patients. Nevertheless, upon closer analysis of the data, Soria et al. (2011) recognised a beneficial trend in the cohort of NSCLC patients expressing GalNT14, the poor prognostic biomarker of NSCLC, suggesting a selective efficacy of TRAIL in GalNT14-positive NSCLC. Clearly, further trials need to be performed on carefully selected patient populations to verify the clinical benefit of TRAIL in specific cancer subgroups.

\section{IAP inhibitors and Smac mimetics}

The role of IAPs in modulating both the apoptotic and necroptotic pathways has led to the screening of small molecules as IAP inhibitors or Smac mimetics, to be used as cancer cell death-promoting agents. As mentioned before, XIAP functions to block caspase activity (Deveraux et al., 1997), as a negative feedback mechanism for the intrinsic apoptotic pathway, whereas Smac promotes apoptosis by inhibiting IAPs (Du et al., 2000). More recently, cIAP1 and cIAP2 were shown to regulate TNFR signalling by stimulating the pro-inflammatory NF- $\kappa \mathrm{B}$ pathway but inhibiting TNFR-dependent apoptosis or necroptosis through the ubiquitylation of complex I (Vandenabeele et al., 2010). Furthermore, IAPs can regulate Ripoptosome-dependent induction of 
apoptosis and necroptosis. In this respect, the recent study by Tenev et al. (2011) demonstrated that the loss of cIAPs induced by Smac mimetics can lead to the activation of the necroptotic pathway and sensitisation of cells to TNF-induced death. Since TNF is often produced during cancer-induced inflammation, the use of Smac mimetics may be an excellent strategy to induce cancer cell death by converting the inflammatory signal to a necroptotic or apoptotic signal.

Indeed, alterations in IAP and Smac proteins have been associated with chemoresistance and poor prognosis in cancer (Hunter et al., 2007; Zeng et al., 2010) and Smac mimetics can sensitise various chemotherapyresistant tumour cells to cisplatin, doxorubicin and TRAIL in vitro and in vivo (Chen and Huerta, 2009). The ability of Smac mimetics to stimulate apoptosis or necroptosis makes them ideal for targeting cancers that may be defective in either of the cell death pathways. Several IAP inhibitors and Smac mimetics are currently being tested in clinical trials for treatment of solid tumours and lymphomas (Gyrd-Hansen and Meier, 2010).

\section{PRIMA-1}

Since p53 is frequently mutated in human cancers, many attempts have been made to restore wild-type p53 function to induce tumour cell death. PRIMA-1 is one such attempt and has been successful in reactivating the wild-type function of mutant p53 and promoting tumour regression in pre-clinical studies (Bykov et al., 2002). The compound is thought to bind to mutant p53 and restore the wild-type conformation, allowing the tumour suppressor protein to engage the apoptotic pathway. PRIMA-1 has also been reported to synergise with conventional chemotherapy to inhibit tumour growth in animal studies (Bykov et al., 2005) and is currently being tested in clinical trials (Wiman, 2010).

\section{Chloroquine}

The acquired resistance of malignant cells to chemotherapy is, in part, attributed to the adaptive pro-survival response conferred by autophagy. This has attracted the use of autophagy inhibitors to enhance the efficacy of chemotherapy. Chloroquine, an autophagy inhibitor, has been reported to sensitise a variety of cancers to conventional chemotherapy in vitro and in vivo (Amaravadi et al., 2007; Solomon and Lee, 2009), and enhance survival of patients with glioblastoma multiforme when used as an adjuvant with conventional chemotherapy or radiotherapy (Briceno et al., 2007).

An exciting development for the use of chloroquine is in combination with the tyrosine kinase inhibitor, imatinib, which primarily targets the constitutively active chimaeric BCR-ABL protein commonly associated with chronic myeloid leukaemia (CML) and to a lesser extent chronic lymphocytic leukaemia and acute lymphoblastic leukaemia (Helgason et al., 2011). Bellodi et al. (2009) previously observed an increase in autophagy levels in CML stem cells treated with imatinib, and the inhibition of autophagy by chloro- quine or ATG5/ATG7 knockdown was able to enhance imatinib-induced cell death. Disease relapse in CML patients is largely due to the persistence of the imatinibresistant, aggressive stem cell pool. Hence, the synergistic effect of autophagy inhibition and imatinib is an appealing strategy for treating such patients, who normally suffer poor prognosis.

More recently, Yang et al. (2011) and Guo et al. (2011) reported an intrinsic autophagy dependency in allogorafts/xenografts from pancreatic cancer cells and cells transformed with oncogenic Ras. In these studies, chloroquine monotherapy was sufficient to promote tumour regression and enhanced survival in these transplanted cancer models. As chloroquine is a welltolerated drug, its potential use as mono- or combination therapy for cancer treatment is highly attractive. Chloroquine is currently being tested in the clinic as monotherapy treatment for pancreatic cancer (http:// www.clinicaltrials.gov: NCT01273805)

\section{Treatments which target both apoptosis and autophagy} In light of the complex interplay between different cell death and autophagic pathways, it is important to consider the potential interactions and complications that may arise when administering cell death- and autophagy-regulating therapies for cancer treatment. For example, due to the convergence between the apoptotic and autophagic pathways at Bcl-2, one would caution the use of $\mathrm{BH} 3$ mimetics on tumours where autophagy is tumour promoting. In these scenarios, BH3 mimetics while promoting apoptosis will also promote autophagy (Maiuri et al., 2007a), which may potentially aggravate the condition. As a result, similar to the situation regarding TRAIL-based therapies as discussed earlier, the importance of personalising treatment regimens according to individual cancers to achieve optimum efficacy and prevent adverse interactions cannot be over-emphasized.

\section{Summary and perspectives}

The awareness that cell death pathways are often disabled in cancers has been an impetus to cancer biologists to target these pathways as an anti-cancer strategy. Although the reactivation of cell death pathways has been found to be challenging, recent studies exploring the cell death machinery has led to the discovery of alternative pathways for modulating cell death (necroptosis and autophagy) and also novel compounds inducing cancer cell demise. This has positively broadened the scope for therapeutic intervention in cancer.

The success of compounds like the $\mathrm{BH} 3$ mimetics, Smac mimetics, TRAIL and PRIMA-1 in pre-clinical studies is a proof of concept that reactivation of defective cell death pathways in cancer cells is not impossible and can effectively eradicate tumour cells. Therefore, it is imperative to push forth efforts to further delineate and identify regulatory components of the different cell death pathways that can be 'drugged' and manipulated to execute death. 
Understanding the interrelationship between the different cell death pathways as well as between cell death and non-cell death pathways in cancer is also crucial in order to spot prospective convergence points between pathways. Targeting the convergence points will allow the switching between pathways and improvisation of alternate means of inducing cancer cell death. For example as highlighted above, TNF signalling to the $\mathrm{NF}-\kappa \mathrm{B}$ pro-survival and inflammatory pathway can be rerouted to the necroptotic pathway to promote cell death just by modulating cIAP levels (Tenev et al., 2011).

Recently, cancer biologists have also homed in on the concept of synthetic lethality to support cancer drug discovery (Chan and Giaccia, 2011). By definition, synthetic lethality occurs when a combination of two or more genetic defects induces cell death, but not when only either of the genes is defective. The screening for potential synthetic lethal interplays within different cancer cells can help uncover new interactions between pathways that can be exploited to kill cancer cells. For example, Scholl et al. (2009) performed a synthetic lethality screen in mutant kras-expressing cancer cells using a high-throughput RNAi knockdown approach to detect genes that are essential for the kras-driven cell viability. The authors discovered that the concomitant knockdown of the STK33 protein kinase could induce death in the mutant kras cells, identifying STK33 as a possible target for kras-related cancers. The knowledge of such potential genetic interactions can subsequently be combined with the use of drugs that target the specific molecules or signalling pathways to prime cancer cells to

\section{References}

Amaravadi RK, Thompson CB. (2007). The roles of therapy-induced autophagy and necrosis in cancer treatment. Clin Cancer Res 13: 7271-7279.

Amaravadi RK, Yu D, Lum JJ, Bui T, Christophorou MA, Evan GI et al. (2007). Autophagy inhibition enhances therapy-induced apoptosis in a Myc-induced model of lymphoma. J Clin Invest 117: $326-336$.

Artal-Sanz M, Samara C, Syntichaki P, Tavernarakis N. (2006). Lysosomal biogenesis and function is critical for necrotic cell death in Caenorhabditis elegans. $J$ Cell Biol 173: 231-239.

Ashkenazi A, Dixit VM. (1998). Death receptors: signaling and modulation. Science 281: 1305-1308.

Azad MB, Chen Y, Henson ES, Cizeau J, McMillan-Ward E, Israels SJ et al. (2008). Hypoxia induces autophagic cell death in apoptosiscompetent cells through a mechanism involving BNIP3. Autophagy 4: $195-204$.

Bellodi C, Lidonnici MR, Hamilton A, Helgason GV, Soliera AR, Ronchetti M et al. (2009). Targeting autophagy potentiates tyrosine kinase inhibitor-induced cell death in Philadelphia chromosomepositive cells, including primary CML stem cells. J Clin Invest $\mathbf{1 1 9}$ : 1109-1123.

Bellot G, Garcia-Medina R, Gounon P, Chiche J, Roux D, Pouyssegur $\mathrm{J}$ et al. (2009). Hypoxia-induced autophagy is mediated through hypoxia-inducible factor induction of BNIP3 and BNIP3 L via their BH3 domains. Mol Cell Biol 29: 2570-2581.

Berry DL, Baehrecke EH. (2007). Growth arrest and autophagy are required for salivary gland cell degradation in Drosophila. Cell 131: $1137-1148$. die. This approach may help enhance the potency of chemotherapy as well as overcome drug resistance of aggressive cancers that are currently unresponsive to treatment.

Cancer research has certainly come a long way. Although we may seem far off from finding a cure for many cancers, the past few decades have successfully led to the identification of pivotal cancer targets (for example, the chimaeric BCR-ABL protein in CML or the oestrogen receptor in breast cancer) and subsequently effective treatments in the clinic today (for example, imatinib against BCR-ABL or tamoxifen against the oestrogen receptor). We may have lost many battles with cancer in the past century, but with the ever expanding understanding of cancer biology, progressive discoveries and encouraging advances in cancer therapy, we should nonetheless be hopeful about winning the war.

\section{Conflict of interest}

The authors declare no conflict of interest.

\section{Acknowledgements}

We apologise to researchers whose studies we were unable to cite due to the length of this review. We thank the members of the Tumour Cell Death Laboratory for critical reading of the manuscript. Work in the Tumour Cell Death Laboratory is supported by Cancer Research UK and the Association for International Cancer Research.

Bertrand MJ, Milutinovic S, Dickson KM, Ho WC, Boudreault A, Durkin J et al. (2008). cIAP1 and cIAP2 facilitate cancer cell survival by functioning as E3 ligases that promote RIP1 ubiquitination. Mol Cell 30: 689-700.

Bianchi K, Meier P. (2009). A tangled web of ubiquitin chains: breaking news in TNF-R1 signaling. Mol Cell 36: 736-742.

Boya P, Kroemer G. (2008). Lysosomal membrane permeabilization in cell death. Oncogene 27: 6434-6451.

Briceno E, Calderon A, Sotelo J. (2007). Institutional experience with chloroquine as an adjuvant to the therapy for glioblastoma multiforme. Surg Neurol 67: 388-391.

Bykov VJ, Issaeva N, Shilov A, Hultcrantz M, Pugacheva E, Chumakov $\mathrm{P}$ et al. (2002). Restoration of the tumor suppressor function to mutant p53 by a low-molecular-weight compound. Nat Med 8: 282-288.

Bykov VJ, Zache N, Stridh H, Westman J, Bergman J, Selivanova G et al. (2005). PRIMA-1(MET) synergizes with cisplatin to induce tumor cell apoptosis. Oncogene 24: 3484-3491.

Cain K, Bratton SB, Langlais C, Walker G, Brown DG, Sun XM et al. (2000). Apaf-1 oligomerizes into biologically active approximately $700-\mathrm{kDa}$ and inactive approximately 1.4-MDa apoptosome complexes. J Biol Chem 275: 6067-6070.

Chan DA, Giaccia AJ. (2011). Harnessing synthetic lethal interactions in anticancer drug discovery. Nat Rev Drug Discov 10: 351-364.

Chan FK, Shisler J, Bixby JG, Felices M, Zheng L, Appel M et al. (2003). A role for tumor necrosis factor receptor-2 and receptorinteracting protein in programmed necrosis and antiviral responses. $J$ Biol Chem 278: 51613-51621. 
Chautan M, Chazal G, Cecconi F, Gruss P, Golstein P. (1999). Interdigital cell death can occur through a necrotic and caspase-independent pathway. Curr Biol 9: 967-970.

Chen DJ, Huerta S. (2009). Smac mimetics as new cancer therapeutics. Anticancer Drugs 20: 646-658.

Ch'en IL, Tsau JS, Molkentin JD, Komatsu M, Hedrick SM. (2011). Mechanisms of necroptosis in T cells. J Exp Med 208: 633-641.

Cheung WC, Kim JS, Linden M, Peng L, Van Ness B, Polakiewicz RD et al. (2004). Novel targeted deregulation of c-Myc cooperates with $\mathrm{Bcl}-\mathrm{X}(\mathrm{L})$ to cause plasma cell neoplasms in mice. J Clin Invest 113 1763-1773.

Chipuk JE, Bouchier-Hayes L, Kuwana T, Newmeyer DD, Green DR. (2005). PUMA couples the nuclear and cytoplasmic proapoptotic function of p53. Science 309: 1732-1735.

Chipuk JE, Green DR. (2008). How do BCL-2 proteins induce mitochondrial outer membrane permeabilization? Trends Cell Biol 18: $157-164$

Cho DH, Jo YK, Hwang JJ, Lee YM, Roh SA, Kim JC. (2009a). Caspase-mediated cleavage of ATG6/Beclin-1 links apoptosis to autophagy in HeLa cells. Cancer Lett 274: 95-100.

Cho YS, Challa S, Moquin D, Genga R, Ray TD, Guildford M et al. (2009b). Phosphorylation-driven assembly of the RIP1-RIP3 complex regulates programmed necrosis and virus-induced inflammation. Cell 137: 1112-1123.

Ciechomska IA, Goemans GC, Skepper JN, Tolkovsky AM. (2009). Bcl-2 complexed with Beclin-1 maintains full anti-apoptotic function. Oncogene 28: 2128-2141.

Cragg MS, Harris C, Strasser A, Scott CL. (2009). Unleashing the power of inhibitors of oncogenic kinases through BH3 mimetics. Nat Rev Cancer 9: 321-326.

Cragg MS, Jansen ES, Cook M, Harris C, Strasser A, Scott CL. (2008). Treatment of B-RAF mutant human tumor cells with a MEK inhibitor requires Bim and is enhanced by a $\mathrm{BH} 3$ mimetic. $J$ Clin Invest 118: 3651-3659.

Cragg MS, Kuroda J, Puthalakath H, Huang DC, Strasser A. (2007). Gefitinib-induced killing of NSCLC cell lines expressing mutant EGFR requires BIM and can be enhanced by $\mathrm{BH} 3$ mimetics. PLoS Med 4: 1681-1689; discussion 1690.

Crighton D, Wilkinson S, O'Prey J, Syed N, Smith P, Harrison PR et al. (2006). DRAM, a p53-induced modulator of autophagy, is critical for apoptosis. Cell 126: 121-134.

Degenhardt K, Mathew R, Beaudoin B, Bray K, Anderson D, Chen G et al. (2006). Autophagy promotes tumor cell survival and restricts necrosis, inflammation, and tumorigenesis. Cancer Cell 10: 51-64.

Degterev A, Boyce M, Yuan J. (2003). A decade of caspases. Oncogene 22: $8543-8567$.

Degterev A, Huang Z, Boyce M, Li Y, Jagtap P, Mizushima N et al. (2005). Chemical inhibitor of nonapoptotic cell death with therapeutic potential for ischemic brain injury. Nat Chem Biol 1: 112-119.

Delavallee L, Cabon L, Galan-Malo P, Lorenzo HK, Susin SA. (2011). AIF-mediated caspase-independent necroptosis: a new chance for targeted therapeutics. IUBMB Life 63: 221-232.

Deter RL, Baudhuin P, De Duve C. (1967). Participation of lysosomes in cellular autophagy induced in rat liver by glucagon. J Cell Biol 35: C11-C16.

Deveraux QL, Takahashi R, Salvesen GS, Reed JC. (1997). X-linked IAP is a direct inhibitor of cell-death proteases. Nature 388: 300-304.

Devin A, Cook A, Lin Y, Rodriguez Y, Kelliher M, Liu Z. (2000). The distinct roles of TRAF2 and RIP in IKK activation by TNF-R1: TRAF2 recruits IKK to TNF-R1 while RIP mediates IKK activation. Immunity 12: 419-429.

Djavaheri-Mergny M, Maiuri MC, Kroemer G. (2010). Cross talk between apoptosis and autophagy by caspase-mediated cleavage of Beclin 1. Oncogene 29: 1717-1719.

Du C, Fang M, Li Y, Li L, Wang X. (2000). Smac, a mitochondrial protein that promotes cytochrome $c$-dependent caspase activation by eliminating IAP inhibition. Cell 102: 33-42.

Eguchi Y, Shimizu S, Tsujimoto Y. (1997). Intracellular ATP levels determine cell death fate by apoptosis or necrosis. Cancer Res $\mathbf{5 7}$ $1835-1840$.
Elmore S. (2007). Apoptosis: a review of programmed cell death. Toxicol Pathol 35: 495-516.

Fadok VA, Bratton DL, Frasch SC, Warner ML, Henson PM. (1998). The role of phosphatidylserine in recognition of apoptotic cells by phagocytes. Cell Death Differ 5: 551-562.

Fanidi A, Harrington EA, Evan GI. (1992). Cooperative interaction between c-myc and bcl-2 proto-oncogenes. Nature 359: 554-556.

Fecker LF, Geilen CC, Tchernev G, Trefzer U, Assaf C, Kurbanov BM et al. (2006). Loss of proapoptotic Bcl-2-related multidomain proteins in primary melanomas is associated with poor prognosis. J Invest Dermatol 126: 1366-1371.

Feoktistova M, Geserick P, Kellert B, Dimitrova DP, Langlais C, Hupe $\mathrm{M}$ et al. (2011). cIAPs block ripoptosome formation, a RIP1/ caspase-8 containing intracellular cell death complex differentially regulated by cFLIP isoforms. Mol Cell 43: 449-463.

Fimia GM, Stoykova A, Romagnoli A, Giunta L, Di Bartolomeo S, Nardacci R et al. (2007). Ambral regulates autophagy and development of the nervous system. Nature 447: 1121-1125.

Fulda S, Debatin KM. (2006). Extrinsic versus intrinsic apoptosis pathways in anticancer chemotherapy. Oncogene 25: 4798-4811.

Fulda S, Meyer E, Debatin KM. (2002). Inhibition of TRAIL-induced apoptosis by Bcl-2 overexpression. Oncogene 21: 2283-2294.

Galluzzi L, Aaronson SA, Abrams J, Alnemri ES, Andrews DW, Baehrecke EH et al. (2009). Guidelines for the use and interpretation of assays for monitoring cell death in higher eukaryotes. Cell Death Differ 16: 1093-1107.

Gdynia G, Grund K, Eckert A, Bock BC, Funke B, MacherGoeppinger S et al. (2007). Basal caspase activity promotes migration and invasiveness in glioblastoma cells. Mol Cancer Res 5: $1232-1240$.

Ghavami S, Hashemi M, Ande SR, Yeganeh B, Xiao W, Eshraghi M et al. (2009). Apoptosis and cancer: mutations within caspase genes. $J$ Med Genet 46: 497-510.

Green DR, Evan GI. (2002). A matter of life and death. Cancer Cell 1: 19-30.

Greenhalgh DG. (1998). The role of apoptosis in wound healing. Int $J$ Biochem Cell Biol 30: 1019-1030.

Guo JY, Chen HY, Mathew R, Fan J, Strohecker AM, KarsliUzunbas G et al. (2011). Activated Ras requires autophagy to maintain oxidative metabolism and tumorigenesis. Genes Dev 25 : $460-470$.

Gyrd-Hansen M, Meier P. (2010). IAPs: from caspase inhibitors to modulators of NF-kappaB, inflammation and cancer. Nat Rev Cancer 10: $561-574$.

Hanahan D, Weinberg RA. (2000). The hallmarks of cancer. Cell 100: $57-70$.

He S, Wang L, Miao L, Wang T, Du F, Zhao L et al. (2009). Receptor interacting protein kinase-3 determines cellular necrotic response to TNF-alpha. Cell 137: 1100-1111.

Healy E, Dempsey M, Lally C, Ryan MP. (1998). Apoptosis and necrosis: mechanisms of cell death induced by cyclosporine $\mathrm{A}$ in a renal proximal tubular cell line. Kidney Int 54: 1955-1966.

Helgason GV, Karvela M, Holyoake TL. (2011). Kill one bird with two stones: potential efficacy of BCR-ABL and autophagy inhibition in CML. Blood 118: 2035-2043.

Hengartner MO. (2000). The biochemistry of apoptosis. Nature 407: $770-776$.

Hetschko H, Voss V, Seifert V, Prehn JH, Kogel D. (2008). Upregulation of DR5 by proteasome inhibitors potently sensitizes glioma cells to TRAIL-induced apoptosis. FEBS J 275: 1925-1936.

Hockenbery D, Nunez G, Milliman C, Schreiber RD, Korsmeyer SJ. (1990). Bcl-2 is an inner mitochondrial membrane protein that blocks programmed cell death. Nature 348: 334-336.

Holler N, Zaru R, Micheau O, Thome M, Attinger A, Valitutti S et al. (2000). Fas triggers an alternative, caspase-8-independent cell death pathway using the kinase RIP as effector molecule. Nat Immunol 1: 489-495.

Hou W, Han J, Lu C, Goldstein LA, Rabinowich H. (2010). Autophagic degradation of active caspase-8: a crosstalk mechanism between autophagy and apoptosis. Autophagy 6: 891-900. 
Hunter AM, LaCasse EC, Korneluk RG. (2007). The inhibitors of apoptosis (IAPs) as cancer targets. Apoptosis 12: 1543-1568.

Kabeya Y, Mizushima N, Ueno T, Yamamoto A, Kirisako T, Noda T et al. (2000). LC3, a mammalian homologue of yeast Apg8p, is localized in autophagosome membranes after processing. EMBO J 19: $5720-5728$.

Kaiser WJ, Upton JW, Long AB, Livingston-Rosanoff D, DaleyBauer LP, Hakem R et al. (2011). RIP3 mediates the embryonic lethality of caspase-8-deficient mice. Nature 471: 368-372.

Kang MR, Kim MS, Oh JE, Kim YR, Song SY, Kim SS et al. (2009). Frameshift mutations of autophagy-related genes ATG2B, ATG5, ATG9B and ATG12 in gastric and colorectal cancers with microsatellite instability. J Pathol 217: 702-706.

Kerr JF, Wyllie AH, Currie AR. (1972). Apoptosis: a basic biological phenomenon with wide-ranging implications in tissue kinetics. $\mathrm{Br} J$ Cancer 26: 239-257.

Kirkin V, Lamark T, Sou YS, Bjorkoy G, Nunn JL, Bruun JA et al. (2009). A role for NBR1 in autophagosomal degradation of ubiquitinated substrates. Mol Cell 33: 505-516.

Koneri K, Goi T, Hirono Y, Katayama K, Yamaguchi A. (2007). Beclin 1 gene inhibits tumor growth in colon cancer cell lines. Anticancer Res 27: 1453-1457.

Koschny R, Holland H, Sykora J, Haas TL, Sprick MR, Ganten TM et al. (2007). Bortezomib sensitizes primary human astrocytoma cells of WHO grades I to IV for tumor necrosis factor-related apoptosis-inducing ligand-induced apoptosis. Clin Cancer Res 13: 3403-3412.

Kosta A, Roisin-Bouffay C, Luciani MF, Otto GP, Kessin RH, Golstein P. (2004). Autophagy gene disruption reveals a nonvacuolar cell death pathway in Dictyostelium. $J$ Biol Chem 279: 48404-48409.

Kuroda J, Puthalakath H, Cragg MS, Kelly PN, Bouillet P, Huang DC et al. (2006). Bim and Bad mediate imatinib-induced killing of $\mathrm{Bcr} / \mathrm{Abl}+$ leukemic cells, and resistance due to their loss is overcome by a BH3 mimetic. Proc Natl Acad Sci USA 103: 14907-14912.

Lavrik I, Golks A, Krammer PH. (2005). Death receptor signaling. $J$ Cell Sci 118: 265-267.

Lee JT, Innes Jr DJ, Williams ME. (1989). Sequential bcl-2 and c-myc oncogene rearrangements associated with the clinical transformation of non-Hodgkin's lymphoma. J Clin Invest 84: 1454-1459.

Leist M, Single B, Castoldi AF, Kuhnle S, Nicotera P. (1997). Intracellular adenosine triphosphate (ATP) concentration: a switch in the decision between apoptosis and necrosis. J Exp Med 185: $1481-1486$.

Leontieva OV, Gudkov AV, Blagosklonny MV. (2010). Weak p53 permits senescence during cell cycle arrest. Cell Cycle 9: 4323-4327.

Leu JI, Dumont P, Hafey M, Murphy ME, George DL. (2004). Mitochondrial p53 activates Bak and causes disruption of a BakMcll complex. Nat Cell Biol 6: 443-450.

Levine B, Yuan J. (2005). Autophagy in cell death: an innocent convict? J Clin Invest 115: 2679-2688.

Li G, Ho VC. (1998). p53-dependent DNA repair and apoptosis respond differently to high- and low-dose ultraviolet radiation. $\mathrm{Br} J$ Dermatol 139: 3-10.

Li H, Zhu H, Xu CJ, Yuan J. (1998). Cleavage of BID by caspase 8 mediates the mitochondrial damage in the Fas pathway of apoptosis. Cell 94: 491-501.

Liang C, Feng P, Ku B, Dotan I, Canaani D, Oh BH et al. (2006). Autophagic and tumour suppressor activity of a novel Beclin1binding protein UVRAG. Nat Cell Biol 8: 688-699.

Liang XH, Jackson S, Seaman M, Brown K, Kempkes B, Hibshoosh $\mathrm{H}$ et al. (1999). Induction of autophagy and inhibition of tumorigenesis by beclin 1. Nature 402: 672-676.

Liang XH, Kleeman LK, Jiang HH, Gordon G, Goldman JE, Berry G et al. (1998). Protection against fatal Sindbis virus encephalitis by beclin, a novel Bcl-2-interacting protein. J Virol 72: 8586-8596.

Lieberthal W, Triaca V, Levine J. (1996). Mechanisms of death induced by cisplatin in proximal tubular epithelial cells: apoptosis vs necrosis. Am J Physiol 270: F700-F708.
Lin Y, Choksi S, Shen HM, Yang QF, Hur GM, Kim YS et al. (2004). Tumor necrosis factor-induced nonapoptotic cell death requires receptor-interacting protein-mediated cellular reactive oxygen species accumulation. J Biol Chem 279: 10822-10828.

Lin Y, Devin A, Rodriguez Y, Liu ZG. (1999). Cleavage of the death domain kinase RIP by caspase-8 prompts TNF-induced apoptosis. Genes Dev 13: 2514-2526.

Lowe SW, Cepero E, Evan G. (2004). Intrinsic tumour suppression. Nature 432: 307-315.

Lum JJ, Bauer DE, Kong M, Harris MH, Li C, Lindsten T et al. (2005). Growth factor regulation of autophagy and cell survival in the absence of apoptosis. Cell 120: 237-248.

Luo S, Rubinsztein DC. (2010). Apoptosis blocks Beclin 1-dependent autophagosome synthesis: an effect rescued by Bcl-xL. Cell Death Differ 17: 268-277.

Luo X, Budihardjo I, Zou H, Slaughter C, Wang X. (1998). Bid, a Bcl2 interacting protein, mediates cytochrome $c$ release from mitochondria in response to activation of cell surface death receptors. Cell 94: 481-490.

Maiuri MC, Criollo A, Tasdemir E, Vicencio JM, Tajeddine N, Hickman JA et al. (2007a). BH3-only proteins and BH3 mimetics induce autophagy by competitively disrupting the interaction between Beclin 1 and Bcl-2/Bcl-X(L). Autophagy 3: 374-376.

Maiuri MC, Le Toumelin G, Criollo A, Rain JC, Gautier F, Juin P et al. (2007b). Functional and physical interaction between Bcl-X(L) and a BH3-like domain in Beclin-1. EMBO J 26: 2527-2539.

Marino G, Salvador-Montoliu N, Fueyo A, Knecht E, Mizushima N, Lopez-Otin C. (2007). Tissue-specific autophagy alterations and increased tumorigenesis in mice deficient in Atg4C/autophagin-3. $J$ Biol Chem 282: 18573-18583.

Martins LM, Iaccarino I, Tenev T, Gschmeissner S, Totty NF, Lemoine NR et al. (2002). The serine protease Omi/HtrA2 regulates apoptosis by binding XIAP through a reaper-like motif. $J$ Biol Chem 277: 439-444.

Massoumi R, Chmielarska K, Hennecke K, Pfeifer A, Fassler R. (2006). Cyld inhibits tumor cell proliferation by blocking Bcl-3dependent NF-kappaB signaling. Cell 125: 665-677.

Mathew R, Karp CM, Beaudoin B, Vuong N, Chen G, Chen HY et al. (2009). Autophagy suppresses tumorigenesis through elimination of p62. Cell 137: 1062-1075.

Mathew R, Kongara S, Beaudoin B, Karp CM, Bray K, Degenhardt K et al. (2007). Autophagy suppresses tumor progression by limiting chromosomal instability. Genes Dev 21: 1367-1381.

Matsunaga K, Saitoh T, Tabata K, Omori H, Satoh T, Kurotori N et al. (2009). Two Beclin 1-binding proteins, Atg14L and Rubicon, reciprocally regulate autophagy at different stages. Nat Cell Biol 11: 385-396.

Mayer B, Oberbauer R. (2003). Mitochondrial regulation of apoptosis. News Physiol Sci 18: 89-94.

McDonnell TJ, Deane N, Platt FM, Nunez G, Jaeger U, McKearn JP et al. (1989). bcl-2-immunoglobulin transgenic mice demonstrate extended B cell survival and follicular lymphoproliferation. Cell 57: 79-88.

McDonnell TJ, Korsmeyer SJ. (1991). Progression from lymphoid hyperplasia to high-grade malignant lymphoma in mice transgenic for the $\mathrm{t}(14 ; 18)$. Nature 349: 254-256.

McKenzie S, Kyprianou N. (2006). Apoptosis evasion: the role of survival pathways in prostate cancer progression and therapeutic resistance. J Cell Biochem 97: 18-32.

Micheau O, Thome M, Schneider P, Holler N, Tschopp J, Nicholson DW et al. (2002). The long form of FLIP is an activator of caspase- 8 at the Fas death-inducing signaling complex. $J$ Biol Chem 277: 45162-45171.

Micheau O, Tschopp J. (2003). Induction of TNF receptor I-mediated apoptosis via two sequential signaling complexes. Cell 114: 181-190.

Mihara M, Erster S, Zaika A, Petrenko O, Chittenden T, Pancoska P et al. (2003). p53 has a direct apoptogenic role at the mitochondria. Mol Cell 11: 577-590.

Miracco C, Cosci E, Oliveri G, Luzi P, Pacenti L, Monciatti I et al (2007). Protein and mRNA expression of autophagy gene Beclin 1 in human brain tumours. Int J Oncol 30: 429-436. 
Miura M. (2011). Active participation of cell death in development and organismal homeostasis. Dev Growth Differ 53: 125-136.

Mizushima N, Ohsumi Y, Yoshimori T. (2002). Autophagosome formation in mammalian cells. Cell Struct Funct 27: 421-429.

Mizushima N, Levine B, Cuervo AM, Klionsky DJ. (2008). Autophagy fights disease through cellular self-digestion. Nature 451: 1069-1075.

Mortimore GE, Schworer CM. (1977). Induction of autophagy by amino-acid deprivation in perfused rat liver. Nature 270: 174-176.

Muller M, Wilder S, Bannasch D, Israeli D, Lehlbach K, Li-Weber M et al. (1998). p53 activates the CD95 (APO-1/Fas) gene in response to DNA damage by anticancer drugs. J Exp Med 188: 2033-2045.

Nakano K, Vousden KH. (2001). PUMA, a novel proapoptotic gene, is induced by p53. Mol Cell 7: 683-694.

Novikoff AB, Essner E, Quintana N. (1964). Golgi apparatus and lysosomes. Fed Proc 23: 1010-1022.

O’Donnell MA, Perez-Jimenez E, Oberst A, Ng A, Massoumi R, Xavier R et al. (2011). Caspase 8 inhibits programmed necrosis by processing CYLD. Nat Cell Biol 13: 1437-1442.

Oberst A, Dillon CP, Weinlich R, McCormick LL, Fitzgerald P, Pop C et al. (2011). Catalytic activity of the caspase-8-FLIP(L) complex inhibits RIPK3-dependent necrosis. Nature 471: 363-367.

Oda E, Ohki R, Murasawa H, Nemoto J, Shibue T, Yamashita T et al. (2000). Noxa, a BH3-only member of the Bcl-2 family and candidate mediator of p53-induced apoptosis. Science 288: 1053-1058.

Odonkor CA, Achilefu S. (2008). Differential activity of caspase-3 regulates susceptibility of lung and breast tumor cell lines to Paclitaxel. Open Biochem J 2: 121-128.

Olopade OI, Adeyanju MO, Safa AR, Hagos F, Mick R, Thompson $\mathrm{CB}$ et al. (1997). Overexpression of BCL-x protein in primary breast cancer is associated with high tumor grade and nodal metastases. Cancer J Sci Am 3: 230-237.

Oltersdorf T, Elmore SW, Shoemaker AR, Armstrong RC, Augeri DJ, Belli BA et al. (2005). An inhibitor of Bcl-2 family proteins induces regression of solid tumours. Nature 435: 677-681.

Pankiv S, Clausen TH, Lamark T, Brech A, Bruun JA, Outzen H et al. (2007). p62/SQSTM1 binds directly to Atg8/LC3 to facilitate degradation of ubiquitinated protein aggregates by autophagy. $J$ Biol Chem 282: 24131-24145.

Pattingre S, Tassa A, Qu X, Garuti R, Liang XH, Mizushima N et al. (2005). Bcl-2 antiapoptotic proteins inhibit Beclin 1-dependent autophagy. Cell 122: 927-939.

Pavet V, Portal MM, Moulin JC, Herbrecht R, Gronemeyer H. (2011). Towards novel paradigms for cancer therapy. Oncogene 30: 1-20.

Qu X, Yu J, Bhagat G, Furuya N, Hibshoosh H, Troxel A et al. (2003). Promotion of tumorigenesis by heterozygous disruption of the beclin 1 autophagy gene. J Clin Invest 112: 1809-1820.

Rampino N, Yamamoto H, Ionov Y, Li Y, Sawai H, Reed JC et al. (1997). Somatic frameshift mutations in the BAX gene in colon cancers of the microsatellite mutator phenotype. Science 275: 967-969.

Rosenfeldt MT, Ryan KM. (2009). The role of autophagy in tumour development and cancer therapy. Expert Rev Mol Med 11: e36.

Rosenfeldt MT, Ryan KM. (2011). The multiple roles of autophagy in cancer. Carcinogenesis 32: 955-963.

Saelens X, Festjens N, Vande Walle L, van Gurp M, van Loo G, Vandenabeele P. (2004). Toxic proteins released from mitochondria in cell death. Oncogene 23: 2861-2874.

Salvesen GS, Renatus M. (2002). Apoptosome: the seven-spoked death machine. Dev Cell 2: 256-257.

Samara C, Syntichaki P, Tavernarakis N. (2008). Autophagy is required for necrotic cell death in Caenorhabditis elegans. Cell Death Differ 15: 105-112.

Sax JK, Fei P, Murphy ME, Bernhard E, Korsmeyer SJ, El-Deiry WS (2002). BID regulation by p53 contributes to chemosensitivity. Nat Cell Biol 4: 842-849.

Scaffidi C, Fulda S, Srinivasan A, Friesen C, Li F, Tomaselli KJ et al. (1998). Two CD95 (APO-1/Fas) signaling pathways. EMBO J 17: 1675-1687.

Schmitt CA, Lowe SW. (1999). Apoptosis and therapy. J Pathol 187: $127-137$
Scholl C, Frohling S, Dunn IF, Schinzel AC, Barbie DA, Kim SY et al. (2009). Synthetic lethal interaction between oncogenic KRAS dependency and STK33 suppression in human cancer cells. Cell 137: 821-834.

Schwarze PE, Seglen PO. (1985). Reduced autophagic activity, improved protein balance and enhanced in vitro survival of hepatocytes isolated from carcinogen-treated rats. Exp Cell Res 157: $15-28$.

Shen S, Kepp O, Michaud M, Martins I, Minoux H, Metivier D et al. (2011). Association and dissociation of autophagy, apoptosis and necrosis by systematic chemical study. Oncogene 30: 4544-4556.

Shimizu S, Kanaseki T, Mizushima N, Mizuta T, Arakawa-Kobayashi S, Thompson CB et al. (2004). Role of Bcl-2 family proteins in a non-apoptotic programmed cell death dependent on autophagy genes. Nat Cell Biol 6: 1221-1228.

Shiraishi H, Okamoto H, Hara H, Yoshida H. (2010). Alternative cell death of Apafl-deficient neural progenitor cells induced by withdrawal of EGF or insulin. Biochim Biophys Acta 1800: 405-415.

Shivapurkar N, Toyooka S, Eby MT, Huang CX, Sathyanarayana UG, Cunningham HT et al. (2002). Differential inactivation of caspase-8 in lung cancers. Cancer Biol Ther 1: 65-69.

Solary E, Dubrez L, Eymin B. (1996). The role of apoptosis in the pathogenesis and treatment of diseases. Eur Respir J 9: 1293-1305.

Soldani C, Scovassi AI. (2002). Poly(ADP-ribose) polymerase-1 cleavage during apoptosis: an update. Apoptosis 7: 321-328.

Solomon VR, Lee H. (2009). Chloroquine and its analogs: a new promise of an old drug for effective and safe cancer therapies. Eur $J$ Pharmacol 625: 220-233.

Soria JC, Mark Z, Zatloukal P, Szima B, Albert I, Juhasz E et al. (2011). Randomized Phase II study of Dulanermin in combination with paclitaxel, carboplatin, and bevacizumab in advanced nonsmall-cell lung cancer. J Clin Oncol 29: 4442-4451.

Tait SW, Green DR. (2010). Mitochondria and cell death: outer membrane permeabilization and beyond. Nat Rev Mol Cell Biol 11: 621-632.

Takahashi Y, Coppola D, Matsushita N, Cualing HD, Sun M, Sato Y et al. (2007). Bif-1 interacts with Beclin 1 through UVRAG and regulates autophagy and tumorigenesis. Nat Cell Biol 9: 1142-1151.

Takamura A, Komatsu M, Hara T, Sakamoto A, Kishi C, Waguri S et al. (2011). Autophagy-deficient mice develop multiple liver tumors. Genes Dev 25: 795-800.

Takimoto R, El-Deiry WS. (2000). Wild-type p53 transactivates the KILLER/DR5 gene through an intronic sequence-specific DNAbinding site. Oncogene 19: 1735-1743.

Tasdemir E, Maiuri MC, Galluzzi L, Vitale I, Djavaheri-Mergny M, D'Amelio M et al. (2008). Regulation of autophagy by cytoplasmic p53. Nat Cell Biol 10: 676-687.

Temkin V, Huang Q, Liu H, Osada H, Pope RM. (2006). Inhibition of ADP/ATP exchange in receptor-interacting protein-mediated necrosis. Mol Cell Biol 26: 2215-2225.

Tenev T, Bianchi K, Darding M, Broemer M, Langlais C, Wallberg F et al. (2011). The ripoptosome, a signaling platform that assembles in response to genotoxic stress and loss of IAPs. Mol Cell 43: 432-448.

Thornborrow EC, Patel S, Mastropietro AE, Schwartzfarb EM, Manfredi JJ. (2002). A conserved intronic response element mediates direct p53-dependent transcriptional activation of both the human and murine bax genes. Oncogene 21: 990-999.

Tsujimoto Y, Cossman J, Jaffe E, Croce CM. (1985). Involvement of the bcl-2 gene in human follicular lymphoma. Science 228 : 1440-1443.

Tsujimoto Y, Finger LR, Yunis J, Nowell PC, Croce CM. (1984). Cloning of the chromosome breakpoint of neoplastic B cells with the t(14;18) chromosome translocation. Science 226: 1097-1099.

Vandenabeele P, Galluzzi L, Vanden Berghe T, Kroemer G. (2010). Molecular mechanisms of necroptosis: an ordered cellular explosion. Nat Rev Mol Cell Biol 11: 700-714.

Vaux DL, Cory S, Adams JM. (1988). Bcl-2 gene promotes haemopoietic cell survival and cooperates with c-myc to immortalize pre-B cells. Nature 335: 440-442. 
Vercammen D, Beyaert R, Denecker G, Goossens V, Van Loo G, Declercq W et al. (1998a). Inhibition of caspases increases the sensitivity of L929 cells to necrosis mediated by tumor necrosis factor. J Exp Med 187: 1477-1485.

Vercammen D, Brouckaert G, Denecker G, Van de Craen M, Declercq W, Fiers W et al. (1998b). Dual signaling of the Fas receptor: initiation of both apoptotic and necrotic cell death pathways. $J$ Exp Med 188: 919-930.

Verhagen AM, Ekert PG, Pakusch M, Silke J, Connolly LM, Reid GE et al. (2000). Identification of DIABLO, a mammalian protein that promotes apoptosis by binding to and antagonizing IAP proteins. Cell 102: 43-53.

Walczak H, Krammer PH. (2000). The CD95 (APO-1/Fas) and the TRAIL (APO-2L) apoptosis systems. Exp Cell Res 256: 58-66.

Wiman KG. (2010). Pharmacological reactivation of mutant p53: from protein structure to the cancer patient. Oncogene 29: 4245-4252.

Wright A, Reiley WW, Chang M, Jin W, Lee AJ, Zhang M et al. (2007). Regulation of early wave of germ cell apoptosis and spermatogenesis by deubiquitinating enzyme CYLD. Dev Cell 13: $705-716$.

Wu Y, Mehew JW, Heckman CA, Arcinas M, Boxer LM. (2001). Negative regulation of bcl-2 expression by p53 in hematopoietic cells. Oncogene 20: 240-251.

Wu YT, Tan HL, Huang Q, Kim YS, Pan N, Ong WY et al. (2008). Autophagy plays a protective role during zVAD-induced necrotic cell death. Autophagy 4: 457-466.

Wu YT, Tan HL, Huang Q, Sun XJ, Zhu X, Shen HM. (2011). zVADinduced necroptosis in L929 cells depends on autocrine production of TNFalpha mediated by the PKC-MAPKs-AP-1 pathway. Cell Death Differ 18: 26-37.

Yang S, Wang X, Contino G, Liesa M, Sahin E, Ying H et al. (2011). Pancreatic cancers require autophagy for tumor growth. Genes Dev 25: $717-729$.
Yang Y, Hu W, Feng S, Ma J, Wu M. (2005). RIP3 beta and RIP3 gamma, two novel splice variants of receptor-interacting protein 3 (RIP3), downregulate RIP3-induced apoptosis. Biochem Biophys Res Commun 332: 181-187.

Yang Z, Klionsky DJ. (2010). Eaten alive: a history of macroautophagy. Nat Cell Biol 12: 814-822.

Yin C, Knudson CM, Korsmeyer SJ, Van Dyke T. (1997). Bax suppresses tumorigenesis and stimulates apoptosis in vivo. Nature 385: $637-640$.

Yu L, Alva A, Su H, Dutt P, Freundt E, Welsh S et al. (2004). Regulation of an ATG7-beclin 1 program of autophagic cell death by caspase-8. Science 304: 1500-1502.

Yue Z, Jin S, Yang C, Levine AJ, Heintz N. (2003). Beclin 1, an autophagy gene essential for early embryonic development, is a haploinsufficient tumor suppressor. Proc Natl Acad Sci USA 100: $15077-15082$.

Zeng H, Zhang S, Yang KY, Wang T, Hu JL, Huang LL et al. (2010). Knockdown of second mitochondria-derived activator of caspase expression by RNAi enhances growth and cisplatin resistance of human lung cancer cells. Cancer Biother Radiopharm 25: 705-712.

Zhang DW, Shao J, Lin J, Zhang N, Lu BJ, Lin SC et al. (2009). RIP3, an energy metabolism regulator that switches TNF-induced cell death from apoptosis to necrosis. Science 325: 332-336.

Zhang H, Zhou X, McQuade T, Li J, Chan FK, Zhang J. (2011) Functional complementation between FADD and RIP1 in embryos and lymphocytes. Nature 471: 373-376.

Zhang J, Stirling B, Temmerman ST, Ma CA, Fuss IJ, Derry JM et al. (2006). Impaired regulation of NF-kappaB and increased susceptibility to colitis-associated tumorigenesis in CYLD-deficient mice. J Clin Invest 116: 3042-3049.

Zong WX, Ditsworth D, Bauer DE, Wang ZQ, Thompson CB. (2004). Alkylating DNA damage stimulates a regulated form of necrotic cell death. Genes Dev 18: 1272-1282. 